Check for updates

Cite this: RSC Adv., 2017, 7, 28092

Received 17th January 2017

Accepted 10th May 2017

DOI: $10.1039 / c 7 r a 00720 e$

rsc.li/rsc-advances

\section{Unique properties of silver and copper silica-based nanocomposites as antimicrobial agents}

\author{
J. Peszke, ${ }^{\text {ab }}$ M. Dulski, (D) ${ }^{\star b c}$ A. Nowak, (D) ${ }^{\text {ab }}$ K. Balin, ${ }^{\text {ab }}$ M. Zubko, ${ }^{c}$ S. Sułowicz, ${ }^{d}$ \\ B. Nowak, ${ }^{e}$ Z. Piotrowska-Seget, ${ }^{d}$ E. Talik, ${ }^{a}$ M. Wojtyniak, ${ }^{\text {ab }}$ A. Mrozek-Wilczkiewicz, ${ }^{\text {ab }}$ \\ K. Malarz ${ }^{\text {bf }}$ and J. Szade ${ }^{\text {ab }}$
}

\begin{abstract}
The paper reports a new route for the fabrication and determination of physicochemical properties and biological activity, of metallic silica-based nanostructure $\left(\mathrm{Ag} / \mathrm{SiO}_{2}, \mathrm{Cu} / \mathrm{SiO}_{2}\right)$. A research studies shows mono-dispersed nanoparticles in silica matrix with an average size of $12 \mathrm{~nm}$ for silver, as well as $12 \mathrm{~nm}$ and $4 \mathrm{~nm}$, respectively for copper in hydrophobic and hydrophilic silica composites. The chemical analysis highlights metallic silver and copper ions heterogeneously distributed in the composite as well as metallic oxides such as $\mathrm{Ag}_{2} \mathrm{O}, \mathrm{Cu}_{2} \mathrm{O}$ and $\mathrm{CuO}$ in hydrophobic system, and $\mathrm{CuO}$ in hydrophilic one. Structural research evidences the presence of amorphous, stoichiometric and non-stoichiometric crystalline phase of silica. Biological studies reveal potentially inhibition of growth gram-positive and gram-negative bacteria as well as microscopic fungi. The size of metal nanoparticles and level of silica hydrophobicity show the highest inhibition bacterial growth for hydrophilic system with embedding inside them, $4 \mathrm{~nm}$ in size copper nanoparticles. Finally, cytotoxic interaction against human cells with respect to silver and copper silica-based nanocomposites was not found.
\end{abstract}

\section{Introduction}

Billions of microorganisms interact with human organism every day. Most microorganisms are symbiotic and helpful; however, $30 \%$ of them are pathogenic and are able to impact human health. Hence, new solutions for elimination of those pathogens are needed. One of the relatively new ideas for pathogens prevention is the fabrication of new materials, which could combine antibacterial or antifungal properties with long-acting times and neutral influence on the environment. One of the potential solution are metallic nanoparticles (NPs) especially silver, copper, zinc or gold. ${ }^{1-3}$ Their antimicrobial effect results from the cell membrane and DNA damages, ${ }^{4}$ interaction with enzymes from thiol groups ${ }^{5}$ or are associated with generating hydrogen peroxide. ${ }^{6}$ What is more, the biocidal properties of metallic NPs strongly depend on particle size, ${ }^{7,8}$ agglomeration ${ }^{\mathbf{9 , 1 0}}$ or release rate of metal ions. ${ }^{\mathbf{1 1 , 1 2}}$ It is believed that their impact on

\footnotetext{
${ }^{a}$ A. Chelkowski Institute of Physics, University of Silesia, Uniwersytecka 4, 40-007, Katowice, Poland

${ }^{b}$ Silesian Center for Education and Interdisciplinary Research, 75 Pułku Piechoty 1A, 41-500 Chorzów, Poland. E-mail: mateusz.dulski@us.edu.pl

${ }^{c}$ Institute of Material Science, University of Silesia, 75 Pułku Piechoty 1a, 41-500, Chorzów, Poland

${ }^{d}$ Department of Microbiology, University of Silesia, Jagiellońska 28, 40-032 Katowice, Poland

${ }^{e}$ Department of Biochemistry, University of Silesia, Jagiellonska 28, 40-032 Katowice, Poland

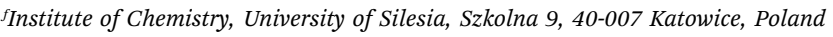

natural environment compared to organic compounds is lower. ${ }^{\mathbf{1 3 , 1 4}}$ Hence, metallic nanoparticles are applied to commonly used organic and inorganic products such as cosmetics, detergents, protective wood paints, dietary supplements or pesticides. ${ }^{15-18}$ The application of metallic NPs has certain limitations linked to the relative ease of leaching of metal ions into the environment. In addition, silver and $\mathrm{TiO}_{2}$ nanoparticles are able to migrate from textile to water, and then with sewage enter into ecosystems. ${ }^{19}$ As a result, metals can easily accumulate in soil, uptake by plants and finally enter into food chain. What is more, there are not possible to completely separate the toxic effect of silver nanoparticles and silver ions. Das et al. have recently demonstrated that to prevent the formation of $\mathrm{Ag}^{+}$ions and to reduce its toxicity, the necessary is to combine them with silica and proteins. ${ }^{20}$ Other solutions are based on fabrication of nanocomposite coatings or by packing metallic nanoparticles in organic or inorganic matrix like polymer, ceramics or glasses. ${ }^{21-23}$ It turned out, that combination of water soluble polymer (PEG) and AgNPs of suitable sizes $(<100 \mathrm{~nm})$ prepared in form of coatings; ${ }^{24-27}$ or combination of metal nanoparticles with magnetite $\left(\mathrm{Fe}_{3} \mathrm{O}_{4}\right)$ NPs improve antibacterial and biomedical properties. ${ }^{28}$ However, the most versatile matrices seems to be composed of chemically modified silica. It was shown that the metal ions embedded into silica matrix have vast potential in a variety of applications; especially as a cytotoxic material for bacteria (silver-based system) ${ }^{\mathbf{2 9}}$ and fungi (copper-based system). ${ }^{29}$ Copper-silica $\left(\mathrm{Cu} / \mathrm{SiO}_{2}\right)$ nanosystem also revealed an excellent anti-corrosion properties, thermal stability and low 
conductivity values. ${ }^{30}$ Moreover, such composites are characterized by slowly discharge of metallic ions from the silica matrix in a long period of time. ${ }^{29}$ It is worth to mention, that in many cases the effectiveness of those nanocomposites depends strongly on their manufacturing techniques; like chemical reactions, ${ }^{31-35}$ solgel $^{\mathbf{3 6}}$ or sputtering deposition. ${ }^{\mathbf{1 4}}$

In this paper, we report a chemical synthesis of copper- and silver- silica dioxide nanocomposites (NCs) in the form of nanopowders. Physicochemical analysis including determination of particle shape, size and morphology, as well as phase identification were performed using X-ray diffraction (XRD), Scanning (SEM) and Transmission (TEM) Electron Microscopy. Molecular interactions between elements and distribution of individual elements in composites were identified in detail by infrared and Raman spectroscopies, energy dispersive X-ray (EDX) and X-ray photoelectron spectroscopy (XPS). Antimicrobial activity of the synthesized NCs against bacteria, yeast and fungi was tested. Finally, the control test of the cytotoxicity was performed on human fibroblast cells (NHDF line).

\section{Nanocomposite synthesis}

Silver and copper silica-based NCs were synthesized by chemical reaction method. The initial materials included two types of silica - hydrophobic $\left(\mathrm{SiO}_{2}{ }^{\mathrm{h}}\right)$ and hydrophilic $\left(\mathrm{SiO}_{2}{ }^{\mathrm{f}}\right)$, sodium hydroxide, nitric acid, ammonia, silver acetate and copper acetate. All commercially available chemicals were purchased in Avantor Company, Gliwice and were analytical grade (purity above 99.99\%). However, the amorphous silica (Orisil 380 and M300) as a matrix for nanocomposite was manufactured by Orisil Ltd., Ukraine.

First stage of preparation route was focused on mixing the silicon dioxide with distilled water and sodium hydroxide. Next, water solution of silver acetate or copper acetate in ammonia, was added to the mixture providing to formation of colloidal suspension. In the last step, concentrated nitric acid was put into stirred colloid. The final product was filtered on polyethylene filter, washed and dried at room temperature to obtain nanopowder. Hereby, three types of nanocomposites were obtained - $\mathrm{Cu}$ combined with hydrophobic and hydrophilic type of $\mathrm{SiO}_{2}$, and $\mathrm{Ag}$ combined with hydrophobic $\mathrm{SiO}_{2}$. Synthesis of $\mathrm{Ag} / \mathrm{SiO}_{2}$ with hydrophilic properties was unsuccessful, yet. The synthesis scheme is presented in Fig. 1.

\section{Analytical methods}

\section{Physicochemical characterization}

The crystallographic structure of $\mathrm{Cu} / \mathrm{SiO}_{2}$ and $\mathrm{Ag} / \mathrm{SiO}_{2}$ composites was studied by X-ray Powder Diffraction (XRD). The XRD data were recorded using Empyrean Panalytical equipment in the Bragg-Brentano geometry using $\mathrm{Cu} \mathrm{K} \alpha$ radiation $(\lambda=1.54$ $\AA)$. The step-scan covered the angular range $20-110^{\circ}$ with the step of $0.02^{\circ}$. The phase analyzes for samples were made with use ICCD PDF-4 database.

The particle shape, size and morphology were in details investigated using Scanning (SEM) and Transmission (TEM) Electron Microscopy, whereas the surface chemical distribution of individual elements and ratio of components were studied, with energy dispersive X-ray (EDX) and X-ray Photoelectron Spectroscopy (XPS). SEM images were obtained by a FE-SEM 7600F Jeol instrument equipped with an Energy Dispersive Xray mode (EDX) to visualize the elemental distribution of $\mathrm{Ag}$ or $\mathrm{Cu}, \mathrm{Si}, \mathrm{O}, \mathrm{C}$ in analyzed area. TEM micrographs were collected with the use JEOL JEM 3010 microscope working at $300 \mathrm{kV}$ equipped with $2 \mathrm{k} \times 2 \mathrm{k}$ Orius TM 833 SC200D Gatan CCD camera. The XPS measurements were taken with the use of Prevac \& VGScienta spectrometer. Monochromatic $\mathrm{Al} \mathrm{K}_{\alpha}$ radiation was used for collecting broad energy range survey spectra as well as spectra of particular core levels including $\mathrm{Ag} 3 \mathrm{~d}, \mathrm{Cu}$ 2p, $\mathrm{O}$ 1s and $\mathrm{C} 1 \mathrm{~s}$. The determination of chemical composition and oxidation states in both $\mathrm{Ag} / \mathrm{SiO}_{2}$ and $\mathrm{Cu} / \mathrm{SiO}_{2}$ systems was included. The spectra were shifted with respect to carbon $\mathrm{C} 1 \mathrm{~s}$ line at $284.6 \mathrm{eV}$ and corrected for the background signal using the integrated Shirley algorithm. The bands were fitted by

A)
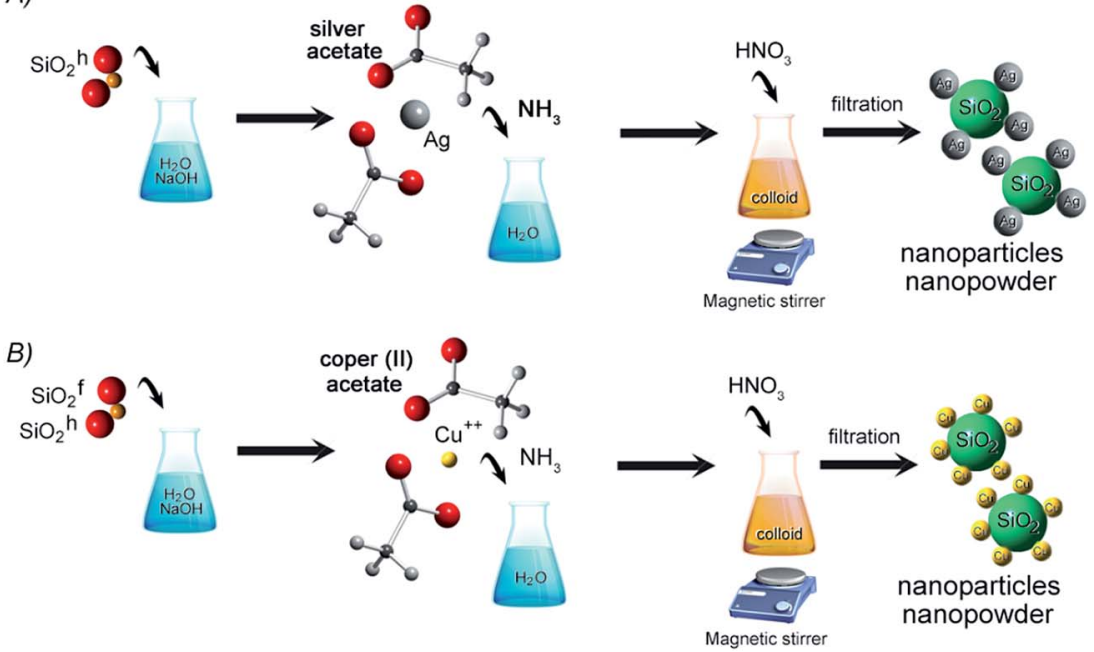

Fig. 1 The synthesis scheme of (A) silver-silica and (B) copper-silica nanocomposites. 
a composition of Gaussian and Lorentzian lines using MultiPak software.

The optical investigation using Infrared (FTIR) and Raman Spectroscopy (RS) were carried out to analyze the material structure as well as the type of molecular interaction between elements in composites. FTIR measurements were carried out using an Agilent Cary 640 FTIR spectrometer equipped with a standard source and a DTGS Peltier-cooled detector. The spectra have been collected using GladiATR diamond accessory in the $450-4000 \mathrm{~cm}^{-1}$ range. All spectra were accumulated with a spectral resolution of $4 \mathrm{~cm}^{-1}$ and recorded by accumulating of 16 scans.

RS investigations were realized using a WITec confocal CRM alpha 300 Raman microscope. The spectrometer was equipped with an air cooled solid state laser operating at $532 \mathrm{~nm}$. A dry Olympus MPLAN $100 \times / 0.9$ NA objective was used. The integration times of $20 \mathrm{~s}$ per spectrum at resolution of $3 \mathrm{~cm}^{-1}$ were applied. The monochromator of the spectrometer was calibrated using Raman scattering line produced by a silicon plate $\left(520.7 \mathrm{~cm}^{-1}\right)$. Finally, the infrared and Raman data were analyzed by baseline correction and using Voigt peak fittings procedure in Grams Software Package.

\section{Antimicrobial properties of nanocomposites}

Spot test. Toxicity of the nanomaterials was examined against 9 different microorganisms: three laboratory strains of bacteria: Escherichia coli (DSM 1103), Pseudomonas putida G7 (DSM 4476), Arthrobacter globiformis (PCM 2134); three yeast strains: Saccharomyces cerevisiae (DSM 70449), Candida tropicalis (DSM 11953), Candida albicans (DSM 1386), and three filamentous fungi: Aspergillus niger Van Tieghem (DSM 1957), Aspergillus terreus Thom (DSM 1958), Scopulariopsis brevicaulis (Saccardo) Bainier (DSM 9122).

The 'spot test' was performed as described in the references ${ }^{37}$ with minor modifications. Briefly, bacterial and yeast cells were cultivated 24 hours in LB and YPD, respectively, at $28^{\circ} \mathrm{C}$, $160 \mathrm{rpm}$. Cells suspension was diluted (1:50 and 1:40 for laboratory bacteria and yeast, respectively) in fresh growth medium and further cultivated $\left(28^{\circ} \mathrm{C}, 160 \mathrm{rpm}\right)$ for $4-6$ hours until mid-exponential growth phase at $\mathrm{OD}_{600} \mathrm{~nm}$ values 0.6 for bacteria and 0.8-1.0 for yeast. The cells were harvested by centrifugation at $4700 \mathrm{rpm}$ for $10 \mathrm{~min}$ at $20^{\circ} \mathrm{C}$ in $50 \mathrm{~mL}$ polypropylene falcon, the pellet was suspended in sterile demineralized (DI) water (Milli-Q, Millipore) and centrifuged again. Finally, the cells were re-suspended in DI water to a density of $\sim 10^{7}$ CFU mL ${ }^{-1}$ for bacteria $\left(\mathrm{OD}_{600 \mathrm{~nm}} 0.1\right)$ and yeast $\left(\mathrm{OD}_{600 \mathrm{~nm}}\right.$ 1.2) as described by Suppi et al. ${ }^{37}$ Filamentous fungi were maintained in test tubes containing Czapek-Dox medium. Cultures were incubated at $30{ }^{\circ} \mathrm{C}$ and humidity up to $90 \%$ for 2 weeks. $5 \mathrm{~mL}$ of sterile $0.2 \%$ SDS solution were poured into test tubes in order to reduce hydrophobicity of fungal spores. After vigorous mixing, the spores were separated from the hyphae by filtration of suspension through sterile cotton wool and centrifugation at $4000 \mathrm{rpm}$. Spores were then re-suspended in sterile DI. After triple washing with water and centrifugation the spore suspension concentration was adjusted to $10^{6}$ spores per $\mathrm{mL}$.

Afterwards, $100 \mu \mathrm{L}$ of cell suspension in DI water was added to $100 \mu \mathrm{l}$ samples of nanomaterials $\mathrm{Ag} / \mathrm{SiO}_{2}{ }^{\mathrm{h}}, \mathrm{Cu} / \mathrm{SiO}_{2}{ }^{\mathrm{h}}, \mathrm{Cu}$ / $\mathrm{SiO}_{2}{ }^{\mathrm{f}}$. As a reference, ion forms of $\mathrm{Ag}$ and $\mathrm{Cu}\left(\mathrm{AgNO}_{3}\right.$ and $\mathrm{CuSO}_{4}$, respectively) were used. All chemicals were tested in six nominal concentrations: $0.01,0.1,1.0,10,100$ and $1000 \mathrm{mg} \mathrm{L}^{-1}$. The stock solutions $\left(2000 \mathrm{mg} \mathrm{L}^{-1}\right.$ ) of $\mathrm{Ag} / \mathrm{SiO}_{2}{ }^{\mathrm{h}}, \mathrm{Cu} / \mathrm{SiO}_{2}{ }^{\mathrm{h}}, \mathrm{Cu} / \mathrm{SiO}_{2}{ }^{\mathrm{f}}$, $\mathrm{AgNO}_{3}$ and $\mathrm{CuSO}_{4}$ were prepared freshly in sterile DI water and homogenized using ultrasonic probe (PolSonic 3) at $2 \times 160 \mathrm{~W}$ for $1 \mathrm{~h}$ just before test. The stocks were diluted in DI water and tested concentrations were incorporated onto 96-well microplates (BD Falcon). Test organisms were exposed to chemicals in DI water at $24{ }^{\circ} \mathrm{C}$ for $24 \mathrm{~h}$ without shaking in the dark. Each experiment was repeated three times.

After 24 hour exposure, $5 \mu \mathrm{L}$ of the cell suspension was pipetted as a 'spot' onto LB or YPD agar plates which were incubated for $24 \mathrm{~h}$ (bacteria) or $72 \mathrm{~h}$ (yeast) at $28^{\circ} \mathrm{C}$. Formation of a visible 'spot' (colonies) was used for determination of the ability of test organisms to grow on agar medium. Minimum biocidal concentration (MBC) of the NCs and ion forms of silver and cooper was determined as the lowest tested concentration which completely inhibited the formation of visible colonies after subculturing on toxicant-free agar media.

\section{Inhibitory concentration $\mathrm{IC}_{50}$}

Inhibitory concentration $\mathrm{IC}_{50}$ of nanomaterials was assessed for bacterial strains: Escherichia coli (DSM 1103), Pseudomonas putida G7 (DSM 4476), Arthrobacter globiformis (PCM 2134). For this purpose, slightly modified method described by Suppi et al. ${ }^{38}$ was used. Bacteria culture from mid-exponential growth phase, obtained as described for 'spot test', were diluted with fresh LB medium to $\mathrm{OD}_{600 \mathrm{~nm}} 0.1$. Subsequently, $50 \mu \mathrm{L}$ of cell suspension was added onto 96 -well microplates to $50 \mu \mathrm{L}$ of six double concentrated solutions of tested compounds prepared in DI water as in 'spot test'. Thereby, the nominal concentrations (0.01, 0.1, 1, 10, 100, $1000 \mathrm{mg} \mathrm{L}{ }^{-1}$ ) of $\mathrm{Ag} / \mathrm{SiO}_{2}{ }^{\mathrm{h}}, \mathrm{Cu} / \mathrm{SiO}_{2}{ }^{\mathrm{h}}$, $\mathrm{Cu} / \mathrm{SiO}_{2}{ }^{\mathrm{f}}, \mathrm{AgNO}_{3}$ and $\mathrm{CuSO}_{4}$ was obtained in rows A-F. As a control, into the row $\mathrm{G} 50 \mu \mathrm{L}$ of DI water without any compound was inoculated by $50 \mu \mathrm{L}$ of cell suspension in LB. Microplates were incubated at $28{ }^{\circ} \mathrm{C}$ without shaking in the dark. Each concentration of the tested chemicals and control culture for each bacterial strain was studied in triplicate. Value of the nanomaterial concentration that makes 50\% inhibition of the bacterial growth with relation to the control was calculated after $24 \mathrm{~h}$ incubation in half-strength LB medium. Such value was based on the curve of inhibition and expressed as means standard deviation (SD).

\section{Toxicity of nanocomposites - cell culture and cytotoxicity assay}

Human fibroblast (NHDF) cells originated from the American Type Culture Collection were the subject of the toxicity test. Cells were grown as monolayer cultures in $75 \mathrm{~cm}^{2}$ flasks (Nunc) in Dulbecco's Modified Eagle Medium (DMEM). The medium was supplemented with 15\% fetal bovine serum (Gibco) and 
$100 \mathrm{mg} \mathrm{L}^{-1}$ of gentamycin (Gibco). The cell lines were maintained at $37{ }^{\circ} \mathrm{C}$ in a $5 \% \mathrm{CO}_{2}$ incubator and passaged every 3-4 days as required. Exponentially growing cells were harvested through the trypsinization of sub-confluent cultures. Cells were seeded into 96-well cell culture microtiter plates (Nunc) at concentrations of $4.0 \times 10^{3}$ cells per well and cultured for $24 \mathrm{~h}$. After this time, the growth medium was exchanged for a medium containing the growing concentrations of the tested compounds. Stock solutions of the compounds being investigated were prepared in sterile DMSO. The highest possible concentration of stock solutions of the tested compounds (in depending on solubility) were prepared in sterile DMSO. The final concentration of DMSO used in the culture medium did not exceed $0.2 \%$ and had no effect on cell growth. After $72 \mathrm{~h}$ of incubation, with the compounds being investigated, under standard cell culture conditions, the medium was replaced with $100 \mu \mathrm{L}$ of DMEM without phenol red. The metabolic activity of viable cells was determined by adding $20 \mu \mathrm{L}$ of CellTiter 96AQueousOne Solutions - MTS (Promega) to each well followed by $1 \mathrm{~h}$ incubation. The MTS assay is a colorimetric method for determining the number of viable cells. A standard solution containing $100 \mu \mathrm{L}$ of DMEM without phenol red and 20 $\mu \mathrm{L}$ of MTS solution was used to determine 'blank' absorbance. The absorbance was measured at $490 \mathrm{~nm}$ using a SynergyTM4 microplate reader (BioTek).

Inhibitory concentration $\left(\mathrm{IC}_{50}\right)$ was also defined for human cells as the compound concentration that was necessary to reduce the proliferation of cells to $50 \%$ of the untreated control cells and expressed as means \pm standard deviation (SD) in GraphPad Prism 5 software. Each individual compound was tested in triplicate.

\section{Cell imaging}

For cell morphology analysis, NHDF cells were seeded in $3 \mathrm{~cm}$ Petri dishes (Nunc) and incubated at $37{ }^{\circ} \mathrm{C}$ for $24 \mathrm{~h}$. Then, the medium was removed and freshly prepared solutions of tested compounds: $\mathrm{Ag} / \mathrm{SiO}_{2}{ }^{\mathrm{h}}\left(100 \mathrm{mg} \mathrm{L}^{-1}\right) ; \mathrm{Cu} / \mathrm{SiO}_{2}{ }^{\mathrm{f}}\left(50 \mathrm{mg} \mathrm{L}^{-1}\right) ; \mathrm{Cu} /$ $\mathrm{SiO}_{2}{ }^{\mathrm{h}}\left(40 \mathrm{mg} \mathrm{L}^{-1}\right)$ were added. After $72 \mathrm{~h}$, the solution of tested compounds was removed and the cells were washed with Phosphate Buffered Saline (PBS) and maintained in DMEM without phenol red. The observation was performed under an inverted Zeiss epifluorescence microscope, Axio Observer Z1 (Carl Zeiss, Germany) in bright field.

\section{Results}

\section{Physicochemical characterization}

$\mathrm{X}$-ray diffraction. The XRD data were collected for silver/and copper/silicon dioxide nanocomposite (Fig. 2). The $\mathrm{SiO}_{2}$ was identified in all samples; amorphous and three silica dioxide phases were detected depend on the matrix. For the $\mathrm{Ag} / \mathrm{SiO}_{2}{ }^{\mathrm{h}}$ nanocomposite a monoclinic $(C 2 / c)$ phase of $\mathrm{SiO}_{2}(01-075-4407)$ with cell parameters $a=6.986 \AA$, $b=12.231 \AA$, $c=7.110 \AA$ and $\beta=120.746^{\circ}$ and a cubic $(F m \overline{3} m)$ phase of $\mathrm{Ag}(04-004-8730)$ with cell parameters $a=4.085 \AA$ were identified. However, the dominant phase originated from the main component of the
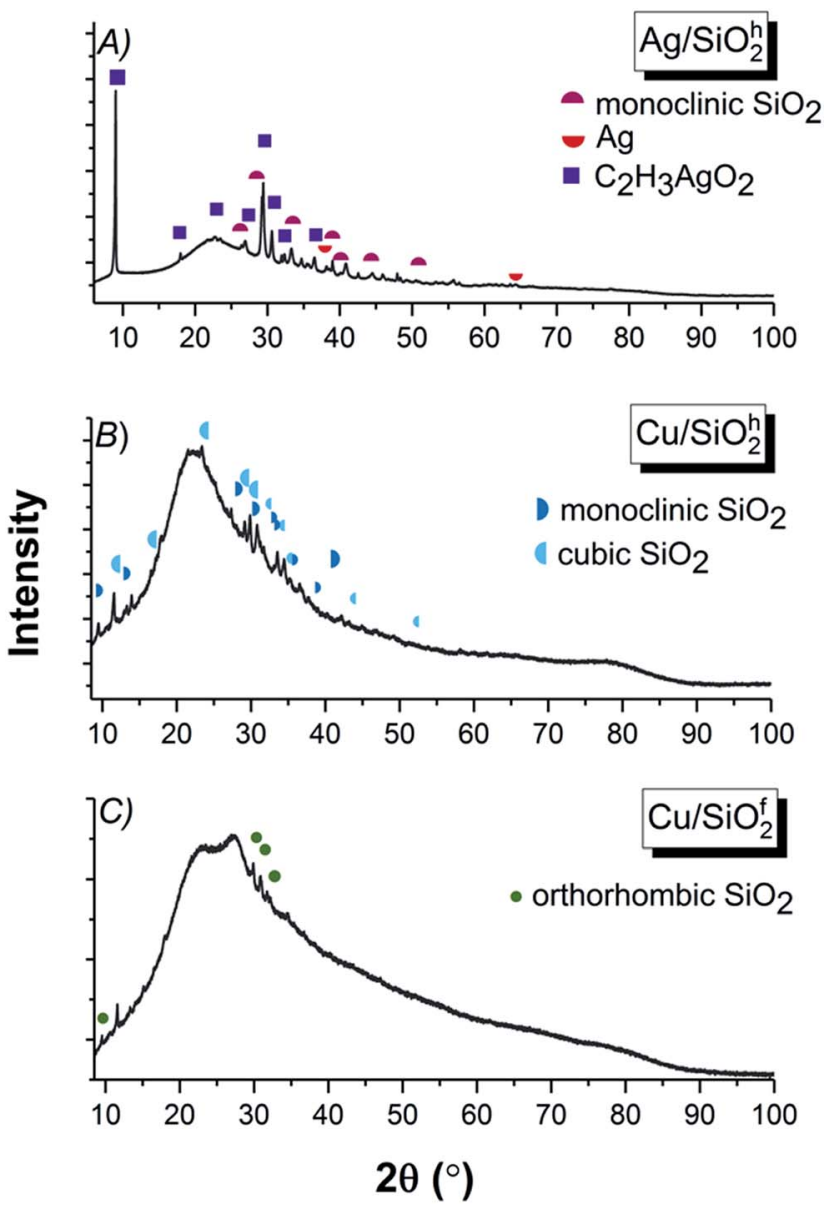

Fig. 2 XRD results for (A) $\mathrm{Ag} / \mathrm{SiO}_{2}{ }^{\mathrm{h}}$, (B) $\mathrm{Cu} / \mathrm{SiO}_{2}{ }^{\mathrm{h}}$ and (C) $\mathrm{Cu} / \mathrm{SiO}_{2}{ }^{\mathrm{f}}$.

synthesis, constitutes the silver acetate (00-057-0335) with $a=$ $6.112 \AA, b=5.594 \AA, c=19.763 \AA$ cell parameters and orthorhombic $\left(C 222_{1}\right)$ space group (Fig. 2A). Due to strong impact of the silicon dioxide the peaks linked to copper on the XRD spectra are difficult to separate with silica. Therefore, in the hydrophobic $\left(\mathrm{SiO}_{2}{ }^{\mathrm{h}}\right)$ sample, two silicon dioxide phases (Fig. 2B) were designated as: monoclinic (01-089-1667) $(P / 21 m)$ with unit cell parameters of $a=9.680 \AA$, $b=19.580 \AA, c=7.400$ $\AA$ and $\beta=81.10^{\circ}$ and cubic (01-075-3901) (Pm $\left.\overline{3} n\right)$ with $a=$ $10.730 \AA$ A. The hydrophilic $\left(\mathrm{SiO}_{2}{ }^{f}\right)$ silicon dioxide system was characterized by the orthorhombic (01-079-0563) (Immm) space group with unit cell parameters of $a=18.557 \AA$, $b=13.889 \AA$ and $c=7.249 \AA$ (Fig. 2C). ${ }^{39}$

Transmission and scanning electron microscopy. To shed more light on the nanostructure of silica based composites, the TEM investigation was performed. The obtained results showed heterogenic distribution of spherical-like $\mathrm{Ag}$ and $\mathrm{Cu}$ nanoparticles dispersed in the silicon dioxide matrix (Fig. 3A-F). Diffraction patterns related to silver showed presence of metallic phase with cell parameters $a=4.086(1) \AA$ while the average size of nanoparticles dispersed in the matrix estimated as 12.55(4) nm. In turn, TEM data supplied XRD outcomes illustrating the presence of copper crystalline structure in hydrophobic and hydrophilic silicon matrix, with $F m \overline{3} m$ space 
A)

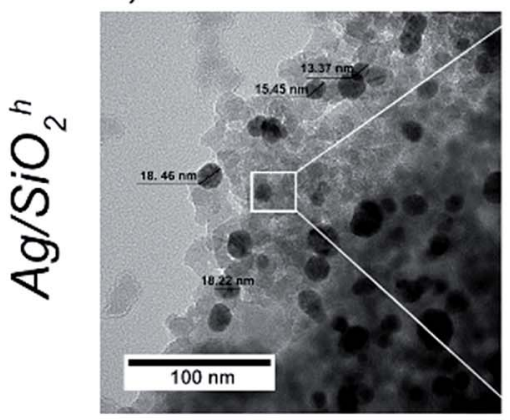

B)

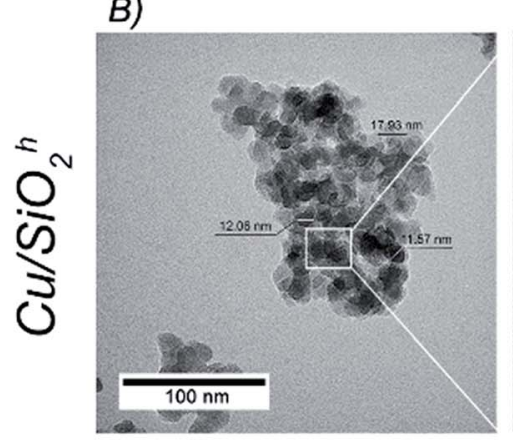

C)

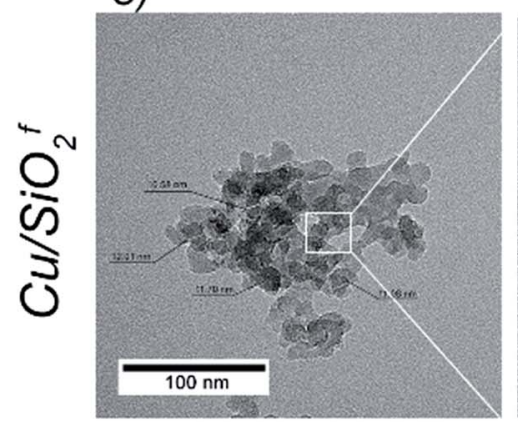

D)

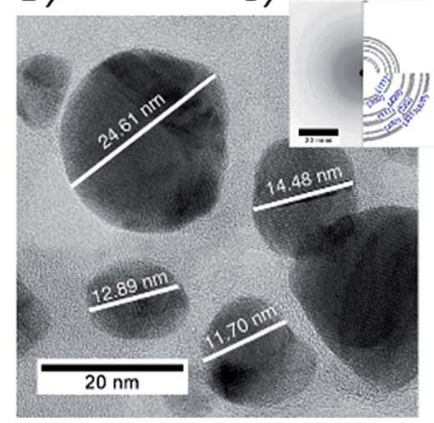

E)

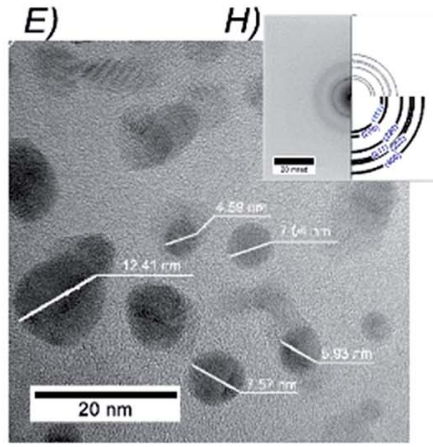

F)

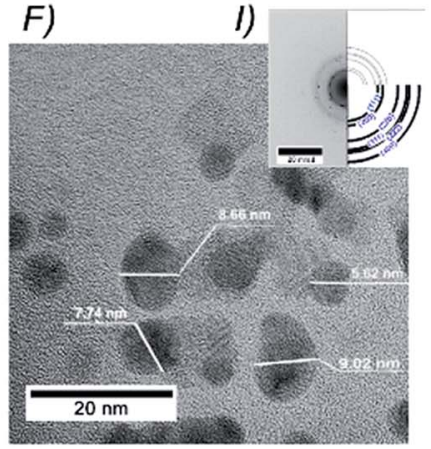

J)

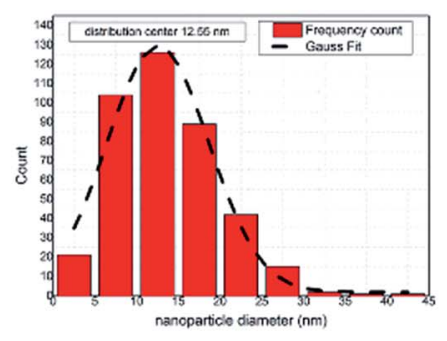

K)

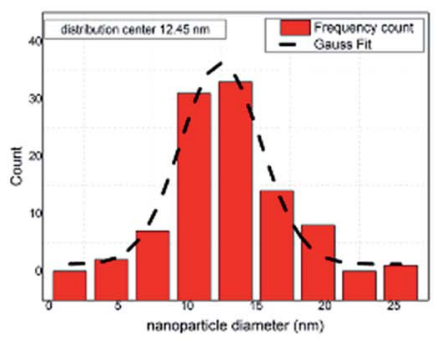

L)

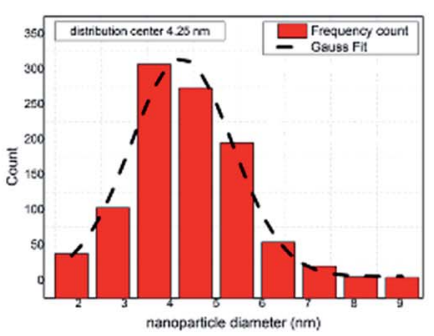

Fig. 3 (A)-(C) TEM micrographs with the scale bar of $100 \mathrm{~nm}$ and (D)-(F) with the scale bar of $20 \mathrm{~nm}$ obtained for $\mathrm{Ag} / \mathrm{SiO}_{2}{ }^{\mathrm{h}}, \mathrm{CuSiO}{ }_{2}{ }^{\mathrm{h}}$ and $\mathrm{Cu} /$ $\mathrm{SiO}_{2}{ }^{f}$ nanocomposites. The brightest objects mean silica matrix, whereas the dark ones are silver or copper particles embedded into the silica matrix. (G)-(I) Insets show SAED patterns for each nanocomposite (left site) with theoretical fitting (right site) while (J)-(L) the particle size distribution for each system was based on three different TEM images.

group and cell parameters $a=3.615(1) \AA$ (SEAD patterns in Fig. 3G-I). The diameter of copper particles in hydrophobic matrix determined with an accuracy to 12.45(5) nm. It turns that the smallest copper nanoparticles identified in hydrophilic copper system with the average size equal to 4.25(8) nm (Fig. 3JL). The morphology of all samples was also investigated by SEM technique. Here, the NPs in silicon dioxide systems formed structures of varying degrees of agglomeration (Fig. 4A-C), with more less homogeneous distribution of $\mathrm{Ag}, \mathrm{Cu}, \mathrm{Si}$ and $\mathrm{O}$ in the whole volume of NC material (Fig. 4D-O). The atomic concentration from the EDX indicated the highest concentration of $\mathrm{Cu}$ in hydrophilic matrix. The analysis also showed the number of carbon atoms, which may result from residues of polymer or basic substance used during synthesis process (see Table 1).

X-ray photoemission spectroscopy. The result obtained from the XPS, surface sensitive technique sensing about $4 \mathrm{~nm}$ thick surface layer, showed that dominant component of the NCs is $\mathrm{SiO}_{2}$. Additionally, the concentration of carbon is lower on the surface, as compared to deeper parts of sample obtained from EDX data. Moreover, lower concentrations of $\mathrm{Ag}$ and $\mathrm{Cu}$ were detected with relation to EDX which gave values of: 95.89\% (Ag/ $\left.\mathrm{SiO}_{2}{ }^{\mathrm{h}}\right), 77.42 \%\left(\mathrm{Cu} / \mathrm{SiO}_{2}{ }^{\mathrm{h}}\right)$ and $91.16 \%\left(\mathrm{Cu} / \mathrm{SiO}_{2}{ }^{\mathrm{f}}\right)$. The more detailed XPS spectral analysis of chemical state of $\mathrm{Ag}, \mathrm{Cu}, \mathrm{Si}, \mathrm{O}$ and $\mathrm{C}$ is shown in Fig. 5. All fitted components of $\mathrm{Ag} 3 \mathrm{~d}, \mathrm{Cu} 2 \mathrm{p}$, Si 2p, O 1s and C 1s core levels have been collected in Table 2.

The analysis of $\mathrm{Ag} 3 \mathrm{~d}_{5 / 2}$ core level (Fig. $5 \mathrm{~A}$ ) in case of $\mathrm{Ag} / \mathrm{SiO}_{2}{ }^{\mathrm{h}}$ system indicates presence of silver in two different chemical states. The binding energy of $368.50 \mathrm{eV}$ is related to pure metallic silver ${ }^{40}$ However, the same binding energy might be assigned to silver ions in silver acetate. Second component with binding energy equal $366.35 \mathrm{eV}$ can be attributed to surface $\mathrm{Ag}$ formed in the $\mathrm{O} / \mathrm{C}-\mathrm{O}$ environment. ${ }^{41}$ In case of chemical states 

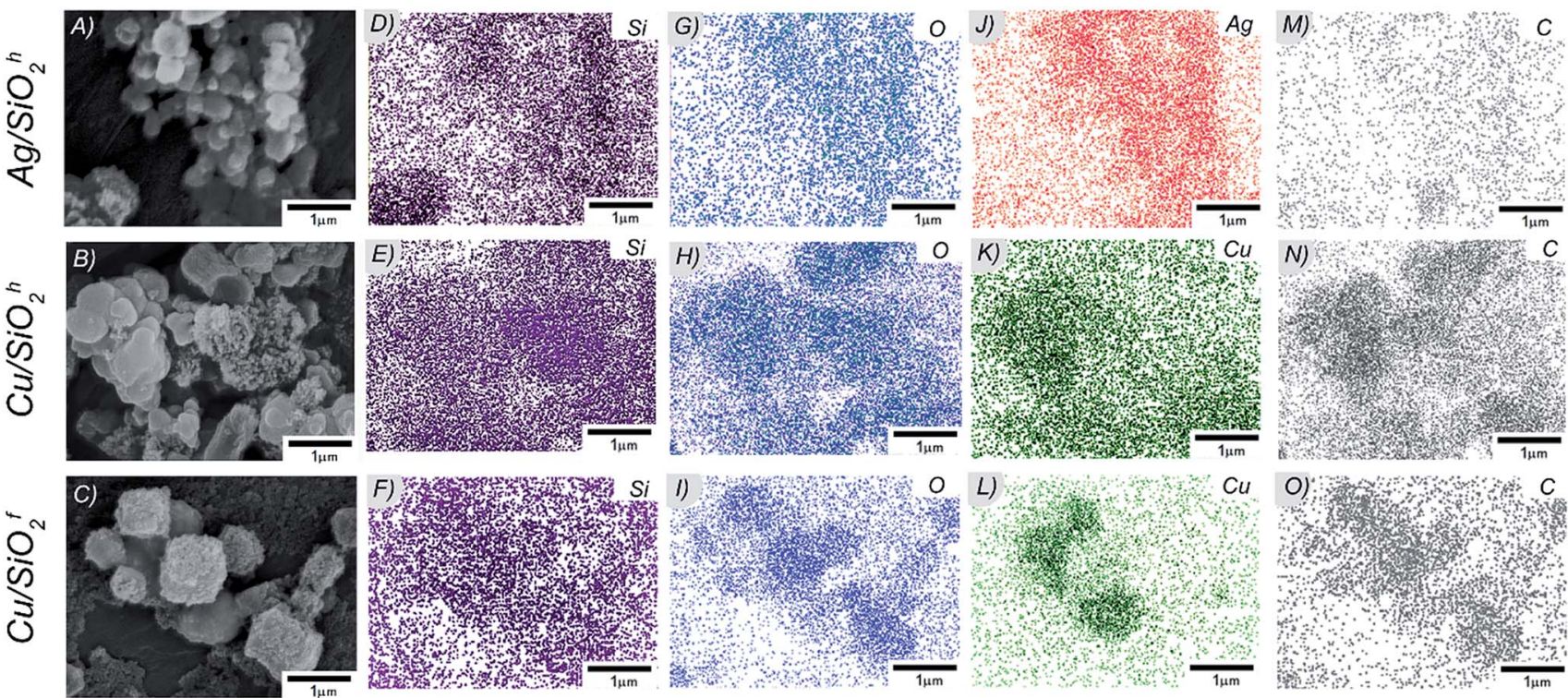

$\mathrm{Cu}$

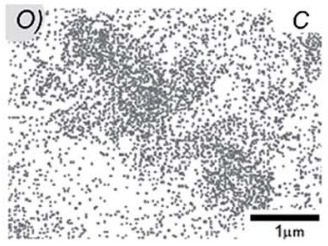

Fig. 4 (A-C) The morphology of the nanocomposites obtained by SEM as well as ( $\mathrm{D}-\mathrm{O}$ ) an individual distribution of Si (violet), $\mathrm{O}$ (dark blue), Ag (red), $\mathrm{Cu}$ (green) and $\mathrm{C}$ (grey) based on the EDX images obtained for $\mathrm{Ag} / \mathrm{SiO}_{2}{ }^{\mathrm{h}}, \mathrm{Cu} / \mathrm{SiO}_{2}{ }^{\mathrm{h}}$ and $\mathrm{Cu} / \mathrm{SiO}_{2}{ }^{\mathrm{f}}$ nanocomposites.

Table 1 Comparison of the atomic concentration resulted from EDX and XPS for $\mathrm{Ag} / \mathrm{SiO} 2$ and $\mathrm{Cu} / \mathrm{SiO}_{2}$ nanocomposites

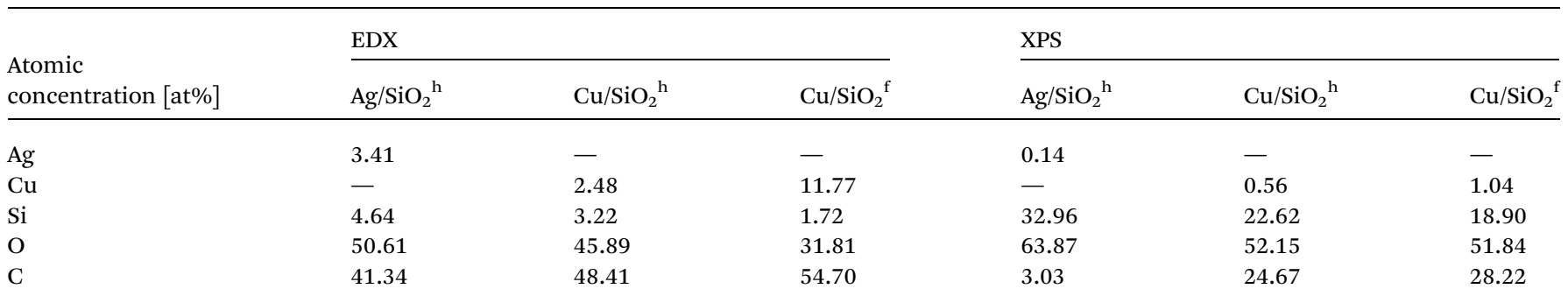
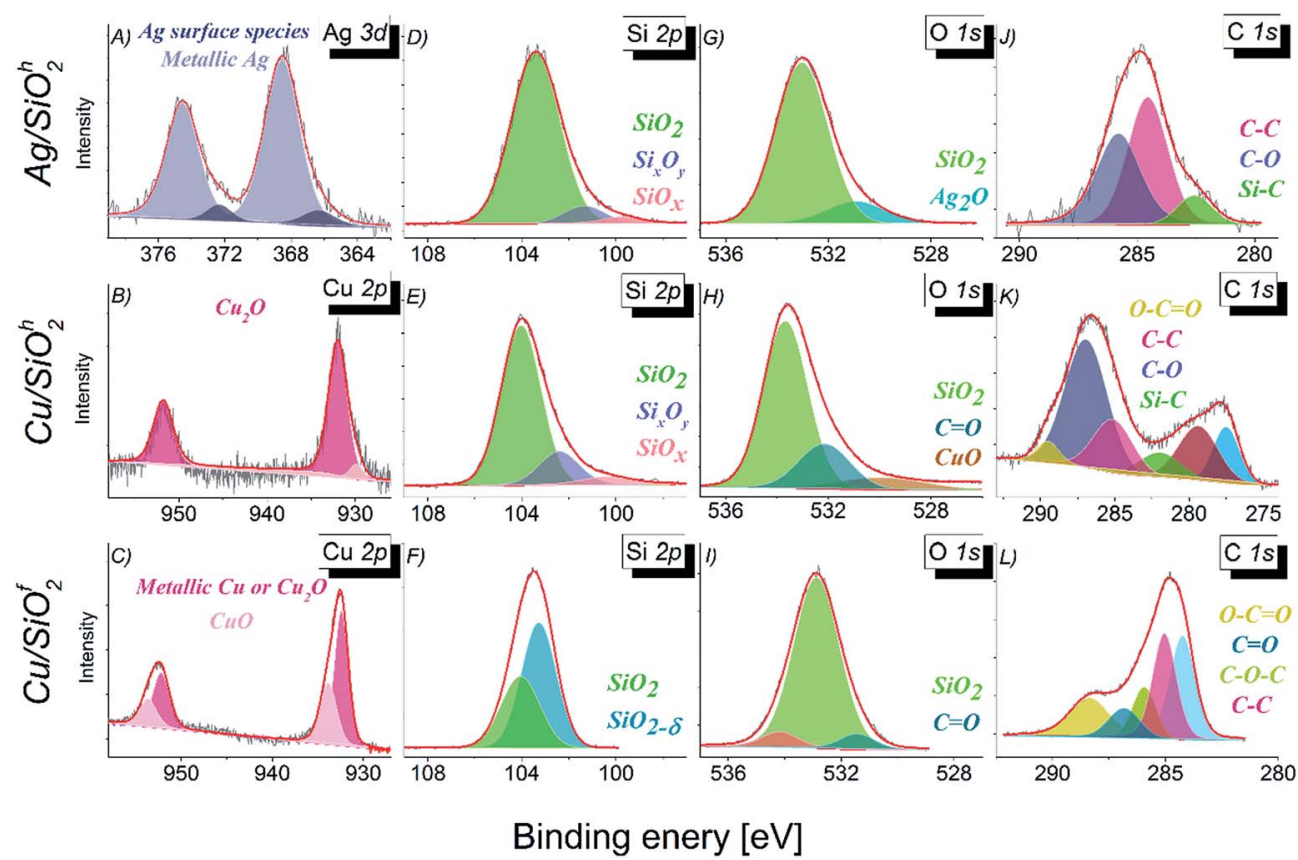

Fig. 5 The XPS spectra with the result of a fitting (A) Ag 3d, (B-C) Cu 2p, (D-F) Si 2p, (G-I) O 1s and (J-L) C 1s. 
Table 2 Binding energies of $\mathrm{Ag} 3 d_{5 / 2}, \mathrm{Cu} 2 p_{3 / 2}$, Si $2 \mathrm{p}, \mathrm{O}$ 1s and $\mathrm{C}$ 1s core levels resolved for $\mathrm{Ag} / \mathrm{SiO}_{2}$ and $\mathrm{Cu} / \mathrm{SiO}_{2}$ systems

\begin{tabular}{|c|c|c|c|c|c|}
\hline \multirow[b]{2}{*}{ System } & \multicolumn{5}{|c|}{ Binding energy $[\mathrm{eV}]$} \\
\hline & $\mathrm{Ag} 3 \mathrm{~d}_{5 / 2}$ & $\mathrm{Cu} 2 \mathrm{p}_{1 / 2}$ & Si $2 p$ & O 1s & C 1s \\
\hline \multirow[t]{3}{*}{$\mathrm{Ag} / \mathrm{SiO}_{2}{ }^{\mathrm{h}}$} & 366.35 & - & 99.7 & 530.9 & 282.6 \\
\hline & 368.5 & & 101.35 & 533.0 & 284.55 \\
\hline & & & 103.4 & & 285.8 \\
\hline \multirow[t]{6}{*}{$\mathrm{Cu} / \mathrm{SiO}_{2}{ }^{\mathrm{h}}$} & - & 929.9 & 100.4 & 530.0 & 277.5 \\
\hline & & & & & 279.4 \\
\hline & & & & & 282.0 \\
\hline & & 932.0 & 102.4 & 532.2 & 285.15 \\
\hline & & & & & 286.9 \\
\hline & & & 104.0 & 533.7 & 289.5 \\
\hline \multirow[t]{4}{*}{$\mathrm{Cu} / \mathrm{SiO}_{2}{ }^{\mathrm{f}}$} & - & 932.5 & 103.3 & 531.4 & 284.25 \\
\hline & & & & 532.9 & 286.8 \\
\hline & & & & & 285.05 \\
\hline & & 933.9 & 104.1 & 534.2 & 285.9 \\
\hline
\end{tabular}

of copper in $\mathrm{Cu} / \mathrm{SiO}_{2}$ systems, two different chemical states were observed (Fig. 5B and C). High binding energy state located at 932.0 eV indicates the presence of $\mathrm{Cu}_{2} \mathrm{O}$ oxide in the $\mathrm{Cu} / \mathrm{SiO}_{2}{ }^{\mathrm{h}}$ sample. ${ }^{42}$ In case of $\mathrm{Cu} / \mathrm{SiO}_{2}{ }^{\mathrm{f}}$ the peak at the $932.5 \mathrm{eV}$ can be assigned to pure metallic state of cooper or $\mathrm{Cu}_{2} \mathrm{O}$ because the binding energies of both chemical states are very close to each other. ${ }^{43}$ The dominant chemical state of copper in $\mathrm{Cu} / \mathrm{SiO}_{2}{ }^{\mathrm{f}}$ sample, in contrast to the one observed in $\mathrm{Cu} / \mathrm{SiO}_{2}{ }^{\mathrm{h}}$, is $\mathrm{CuO}$ (Table 2). The presence of $\mathrm{SiO}_{2}$ compound, as mentioned above has been confirmed for $\mathrm{Ag} / \mathrm{SiO}_{2}$ and $\mathrm{Cu} / \mathrm{SiO}_{2}$ systems (Fig. 5DF) ${ }^{40,44}$ The analysis of $\mathrm{Si} 2 \mathrm{p}$ line indicated presence of the nonstoichiometric $\mathrm{SiO}_{x}$ oxides. ${ }^{44}$ The other phase of $\mathrm{SiO}_{2}$ has been detected in $\mathrm{Cu} / \mathrm{SiO}_{2}{ }^{\mathrm{f}}$ where the atypical non-stoichiometric $\mathrm{SiO}_{2-\delta}$ oxide constitutes the dominant component, while the stoichiometric $\mathrm{SiO}_{2}$ has a smaller contribution to the $\mathrm{Si} 2 \mathrm{p}$ core line. The shape analysis of the $\mathrm{O} 1 \mathrm{~s}$ core level (Fig. 5G-I) has confirmed the dominant character of $\mathrm{SiO}_{2}$ compound in all systems.

Additionally, the oxygen states indicate presence of $\mathrm{Ag}_{2} \mathrm{O}$ oxide $(530.9 \mathrm{eV}),{ }^{40} \mathrm{CuO}$ oxide $(530.0 \mathrm{eV})$, as well as chemical states which can be related to bonding between carbon and oxygen. The one at lower binding energy is originating from the double $\mathrm{C}=\mathrm{O}$ bonding $\left(\mathrm{Cu} / \mathrm{SiO}_{2}{ }^{\mathrm{h}}\right)$, whereas the one of the higher binding energy in case of $\mathrm{Cu} / \mathrm{SiO}_{2}{ }^{\mathrm{f}}$ to the polymer like bonding. Finally, the photoemission spectra of $\mathrm{C} 1 \mathrm{~s}$ core level has revealed the typical organic components like $\mathrm{C}-\mathrm{O}, \mathrm{C}-\mathrm{C}$ and $\mathrm{C}=\mathrm{O}$ bonds. ${ }^{40,45-47}$ This can be a consequence of the presence of residues remaining in the samples after the synthesis process or environment adsorbents containing carbon (Fig. 5J-L).

FTIR analysis. To resolve the problem of FTIR spectra interpretation of NCs, reference spectra of the pure $\mathrm{SiO}_{2}, \mathrm{Ag}$ and $\mathrm{Cu}$ were presented (Fig. 6A-C). The results showed, that the $\mathrm{SiO}_{2}$ spectrum is dominated by three characteristic absorption bands at $450-1500 \mathrm{~cm}^{-1}$, which originate from $\mathrm{Si}-\mathrm{O}-\mathrm{Si}$ vibrations. ${ }^{1,48,49}$ The band at $952 \mathrm{~cm}^{-1}$ is ascribed to the $\mathrm{Si}-\mathrm{OH}$ bond, ${ }^{1,49,50}$ while the rest of the them stems from structural deformation within silica network and from non-stoichiometric silicon oxide. ${ }^{51}$ The pure Ag sample showed characteristic bands

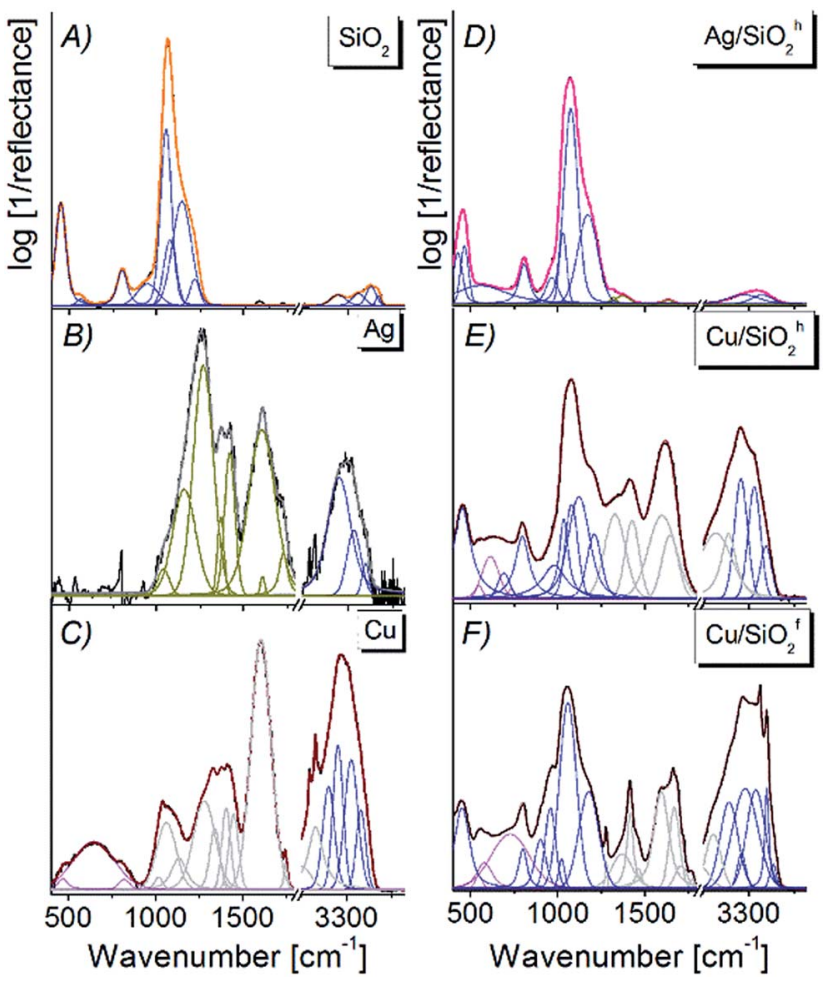

Fig. 6 FTIR spectra of (A) pure silica, (B) $\mathrm{Ag},(\mathrm{C}) \mathrm{Cu}$, (D) $\mathrm{Ag} / \mathrm{SiO}_{2}{ }^{\mathrm{h}},(\mathrm{E})$ $\mathrm{Cu} / \mathrm{SiO}_{2}{ }^{\mathrm{h}}$, (F) $\mathrm{Cu} / \mathrm{SiO}_{2}{ }^{\mathrm{f}}$ nanocomposites spectra fitted by Voigt function in the $450-4000 \mathrm{~cm}^{-1}$ range.

in the $1100-1800 \mathrm{~cm}^{-1}$ range (Fig. 6B) arouse from silver nanoparticles as well as bands of the hydroxyl groups in form of the shell layer around the them in the $3200-3800 \mathrm{~cm}^{-1}$ range. FTIR data for $\mathrm{Cu}$ sample revealed presence of bands resulting mainly from $\mathrm{CH}_{2}$ and $\mathrm{OH}$ modes due to the presence of organic carbon as well as bands centered in the $600-700 \mathrm{~cm}^{-1}$ range corresponding to the $\mathrm{Cu}-\mathrm{O}$ stretching vibration ${ }^{1}$ (Fig. 6D).

Analyzing the $\mathrm{Ag} / \mathrm{SiO}_{2}{ }^{\mathrm{h}}$ spectrum, one can find the slight redshift about $10 \mathrm{~cm}^{-1}$ and broadening of main silica band, due to formation of the $\mathrm{Si}-\mathrm{O}-\mathrm{Ag}$ bond ${ }^{48}$ At the same time, the splitting of Si-O-Si band centered originally at $445 \mathrm{~cm}^{-1}$ on two bands centered at $429 \mathrm{~cm}^{-1}$ and $465 \mathrm{~cm}^{-1}$ points to the deformation of silica network as well as formation of the outer polymeric cage within silica network (Fig. 6C). ${ }^{48,52}$ Further analysis showed weak intense bands observed on silver-silica infrared spectra located in the $1650-1750 \mathrm{~cm}^{-1}$ range. This band corresponds to the stretching vibration of $\mathrm{C}=\mathrm{O}$ bond from the aldehyde group, while bands located in the $3200-3800 \mathrm{~cm}^{-1}$ range can be associated with stretching mode of $\nu(\mathrm{Si}-\mathrm{OH}), \nu(\mathrm{OH})$ as well as molecular water adsorbed on the silica surface. ${ }^{1,49,53}$ Interestingly, an increase in the $3200-3800 \mathrm{~cm}^{-1}$ bands result from an increase amount of hydroxyl groups due to their localization over the AgNPs and effectively embedded silver nanoparticles inside the $\mathrm{SiO}_{2}$ frame. At the same time, a modification in band intensity results from an increase in the number of an intermolecular H-bonding interaction are associated with a hydrogen bond scheme realized by the combination of Si-OSi framework and hydroxide from AgNPs modifier. 
The $\mathrm{Cu} / \mathrm{SiO}_{2}$ spectrum is dominated by polymer-like bands (1300-3800 $\left.\mathrm{cm}^{-1}\right)$, partially overlapping with silica and organic carbon (400-1300 $\left.\mathrm{cm}^{-1}\right)$ ones. The deconvolution procedure and peak fitting analysis revealed presence of $\mathrm{Cu}-\mathrm{O}(600-700$ $\left.\mathrm{cm}^{-1}\right)$, Si-O-Si $\left(450-1500 \mathrm{~cm}^{-1}\right)$ and $\mathrm{Si}-\mathrm{OH}\left(950 \mathrm{~cm}^{-1}, 3000\right.$ $\mathrm{cm}^{-1}$ ) vibrations. The bands located at $600-1250 \mathrm{~cm}^{-1}$ might be assigned to the deformation of $\delta(\mathrm{Cu}-\mathrm{O}-\mathrm{Si})$ bonds located at the interface between $\mathrm{CuO}$ and $\mathrm{SiO}_{2} \cdot{ }^{1}$ In addition, sharper bands observed in the hydroxyl region of $\mathrm{Cu} / \mathrm{SiO}_{2}{ }^{\mathrm{f}}$ suggest higher contribution of hydroxide than for hydrophobic composite (Fig. 6E and F). High band intensities in this range also determine the formation of hydrogen bonding of copper nanoparticles with silica matrix.

Raman analysis. Further, more local analysis with respect to FTIR data have been performed using Raman spectroscopy (RS). The reference RS data for pure $\mathrm{SiO}_{2}$ system is presented in Fig. 7A (reference spectra of pure $\mathrm{Ag}$ and $\mathrm{Cu}$ NPs) were previously reported by Nowak et al. ${ }^{33}$ The data for pure silica showed presence of peaks assigned to: the rotational modes of the silica structural units $\left(235,308 \mathrm{~cm}^{-1}\right)$ and vibrational active modes within silica skeleton to bands at $391 \mathrm{~cm}^{-1}\left(\omega_{1}\right), 478 \mathrm{~cm}^{-1}$ (D1), $606 \mathrm{~cm}^{-1}(\mathrm{D} 2), 804 \mathrm{~cm}^{-1}\left(\omega_{3}\right)$ and $1055 \mathrm{~cm}^{-1}\left(\omega_{4}\right)$ (see Fig. 7A

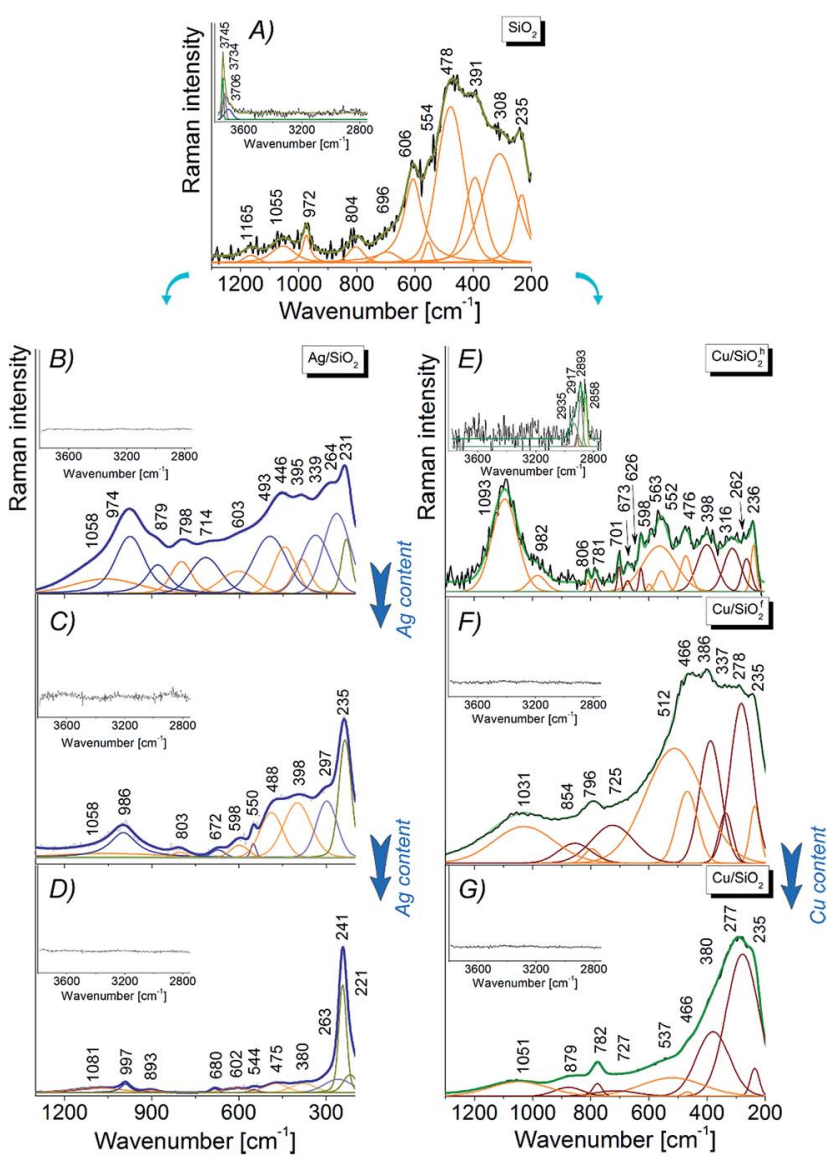

Fig. 7 Raman spectra of (A) pure silica, (B-D) silver-silicon oxide depends on the Ag content as well as (E) $\mathrm{Cu} / \mathrm{SiO}_{2}{ }^{\mathrm{h}}$, (F) Cu/SiO${ }_{2}{ }^{\mathrm{f}}$ and (G) copper-rich silica with the Voigt peak fitted curves in the 1250-200 $\mathrm{cm}^{-1}$ range. The insets showed magnified hydroxyl stretching region between $3800-2800 \mathrm{~cm}^{-1}$. and Table 4)..$^{54-62}$ The position of band at $391 \mathrm{~cm}^{-1}$ depends strongly on the particle size of silicon oxide i.e. the smaller the particle, the higher wavenumber of the band. ${ }^{63}$ Two Raman bands, labeled D1 and D2, arise from the three-member and four-member silicon-oxygen (i.e. siloxane) ring structures. ${ }^{64}$ Raman bands located at about $1000 \mathrm{~cm}^{-1}$ corresponds to silicon-oxygen stretching modes of $\mathrm{SiO}_{4}$ group with four, three, two or one non-bridging oxygen in siloxane ring. ${ }^{60}$ The other bands can be attributed to the structural deformation of silica network as well as the presence of hydroxyl groups attached to the silica skeleton.

Physicochemical properties of nanocomposites are strongly influenced by the concentration of metal embedded into the matrix. Thus, adding network modifiers, such as silver, copper or carbon, substantially changes the initial silica structure generating additional bands as well as changing intensity of other ones. ${ }^{54}$ Looking more closely on the $\mathrm{Ag} / \mathrm{SiO}_{2}{ }^{\mathrm{h}}$ spectrum (Fig. 7B) one can observe few low wavenumber bands ascribed to $\mathrm{Si}-(\mathrm{O}-\mathrm{Ag})$ modes. ${ }^{65,66}$ The differences at $\omega_{1}, \mathrm{D} 2$ band positions are probably due to deformation of silica network, while the red-shift of D1 band for about $20 \mathrm{~cm}^{-1}$ with respect to pure silica, arise from elongation of $\mathrm{Si}-\mathrm{O}$ bond within three-fold ring silica structure. Above the $700 \mathrm{~cm}^{-1}$ range, the Raman bands are generally assigned to $-\mathrm{Si}-\mathrm{O}^{*}$ structural elements which are characteristic for crystalline silica phase. ${ }^{54,64,67}$ Interestingly, an increase of Ag content gradually amplifies the band intensity at $235 \mathrm{~cm}^{-1}$, which originates from $\mathrm{Si}-(\mathrm{O}-\mathrm{Ag})$ mode (Fig. 7B and C) and the blue or red-shift band. This is an effect of silver interaction with silicon oxide network e.g. red-shift bands assigned to - $\mathrm{Si}-\mathrm{O}^{*}$ structural elements suggest elongation of $\mathrm{Si}-$ O bond..$^{54,64,67}$ Finally, no bands associated with hydroxyl groups have been detected (Fig. 7B-D). On the other hand, Raman spectra of $\mathrm{Cu} / \mathrm{SiO}_{2}$ systems strongly depend on the type of silica type (Fig. $7 \mathrm{E}$ and F). For hydrophobic $\mathrm{Cu} / \mathrm{SiO}_{2}{ }^{\mathrm{h}}$ system a small shift $\left(\mathrm{few} \mathrm{cm}^{-1}\right.$ ) with respect to pure silica is an effect of relatively small interaction of copper on amorphous silica network, ${ }^{54,68}$ while the existence of additional lines indicates a copper-oxide bond (see Table 3). Moreover, two bands located at $262,626 \mathrm{~cm}^{-1}$ can be assigned to $(\mathrm{Cu}-\mathrm{O})-\mathrm{Si}$ mode. ${ }^{69,70}$ Further, bands at $563,673 \mathrm{~cm}^{-1}$ can be assigned to $\left(\mathrm{Cu}_{2}-\mathrm{O}\right)-\mathrm{Si}$ vibration, ${ }^{71}$ while bands at $701,781 \mathrm{~cm}^{-1}$ suggest structural deformation of silica network. Interestingly, high intensity of line at $1093 \mathrm{~cm}^{-1}$ suggest statistically high amount of $-\mathrm{Si}-\mathrm{O}^{*}$ structural groups coming from crystalline silica. In addition, weak band found between $3200-2800 \mathrm{~cm}^{-1}$ indicates presence of organic moieties (C-H) confirmed by the SEM and XPS data. In case of hydrophilic $\mathrm{Cu} / \mathrm{SiO}_{2}{ }^{\mathrm{f}}$ system, amorphous silica-bands are shifted $\pm 10 \mathrm{~cm}^{-1}$ due to strong copper interaction with $\mathrm{SiO}_{2}$ activating the (Si-O)-Cu vibration..$^{72}$ Similar to hydrophobic system, two bands at $1031,854 \mathrm{~cm}^{-1}$ are an evidence of the -Si$\mathrm{O}^{*}$ structural elements originating from the crystalline silica. ${ }^{54,64}$ The intensities of all bands are closely related to those from pure silica suggesting only a weak interaction of copper with silica network. The increase of copper content in both samples lead to overlapping of bands arising from copper oxide and silica vibration. In that way, Raman spectrum of highly content copper-silica spectrum is dominated by bands at 277 , 
Table 3 The Raman bands assignment for pure $\mathrm{SiO}_{2}, \mathrm{Ag} / \mathrm{SiO}_{2}$ and $\mathrm{Cu} / \mathrm{SiO}_{2}$ nanosystems

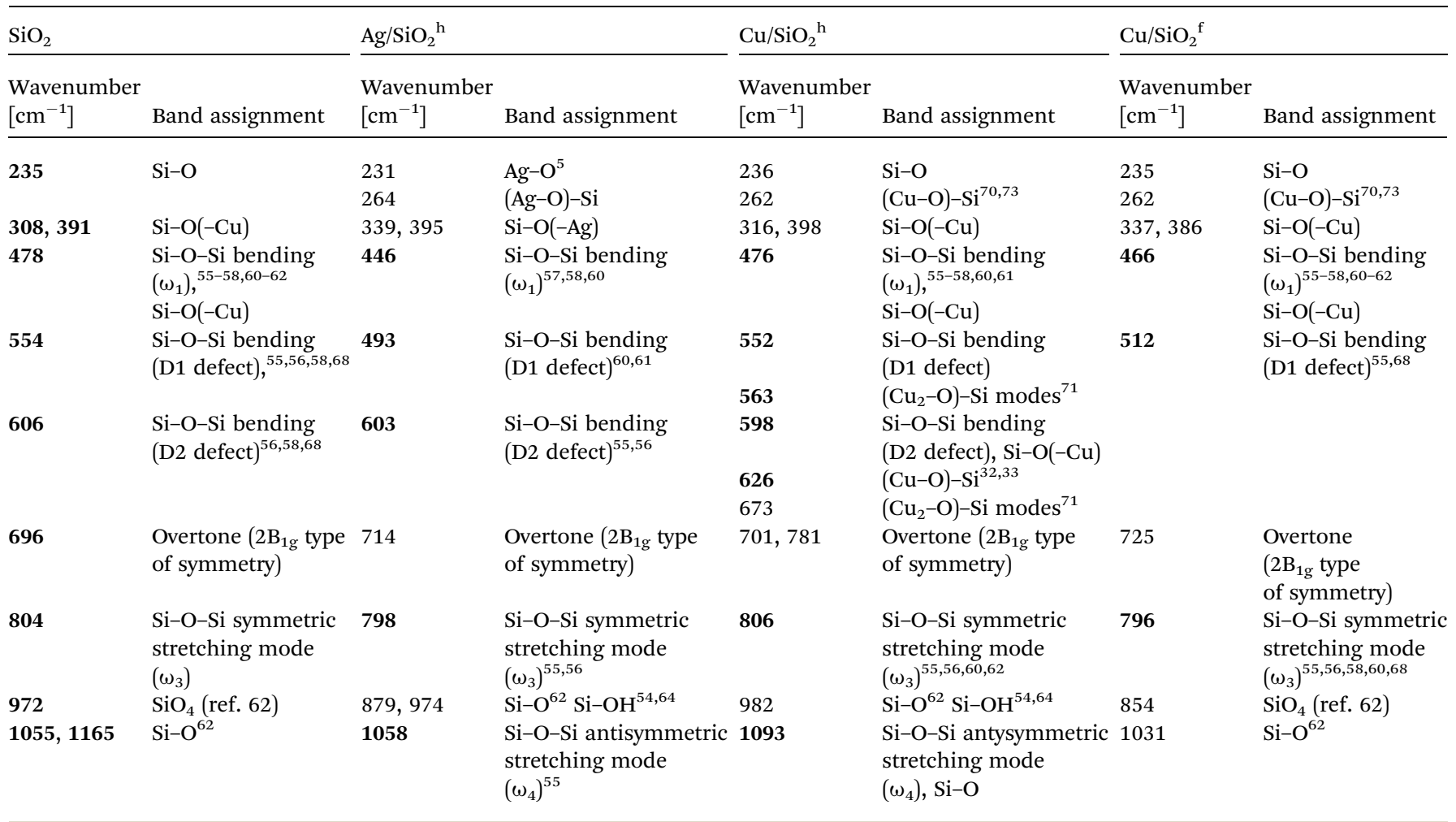

Table 4 Minimum biocidal concentration (MBC) of tested on bacteria, yeast and microscopic fungi nanocomposites after $24 \mathrm{~h}$ exposure in deionized water at $24^{\circ} \mathrm{C}$ in nominal concentrations from 0.01 up to $1000 \mathrm{mg} \mathrm{L}^{-1}$. The results of tests of NCs have been combined with tests on $\mathrm{AgNO}_{3}$ and $\mathrm{CuSO}_{4}$. All experiments were done in three replicates and average data from summarized. Different colors indicated different $\mathrm{MBC}$ values

\begin{tabular}{|c|c|c|c|c|c|c|}
\hline \multicolumn{2}{|c|}{ Strain } & $\mathrm{Ag} / \mathrm{SiO}_{2}{ }^{\mathrm{h}}$ & $\mathrm{Cu} / \mathrm{SiO}_{2}{ }^{\mathrm{f}}$ & $\mathrm{CuSiO}_{2}{ }^{\mathrm{h}}$ & $\mathrm{AgNO}_{3}$ & $\mathrm{CuSO}_{4}$ \\
\hline \multirow{5}{*}{ Bacteria } & E. coli & 1000 & 10 & 1000 & 1 & 10 \\
\cline { 2 - 7 } & P. putida & 1000 & 10 & $>1000$ & 1 & 10 \\
\cline { 2 - 7 } & globiformis & 1000 & 10 & $>1000$ & 10 & 10 \\
\hline \multirow{5}{*}{ Yeast } & S. cerevisiae & $>1000$ & 1000 & $>1000$ & 10 & 100 \\
\cline { 2 - 7 } & C. arborea & $>1000$ & 1000 & $>1000$ & 100 & 1000 \\
\cline { 2 - 7 } & C. albicans & $>1000$ & 1000 & $>1000$ & 100 & 1000 \\
\hline & A. niger & $>1000$ & 1000 & $>1000$ & 100 & $>1000$ \\
\cline { 2 - 7 } & A. terreus & $>1000$ & 10 & $>1000$ & 1 & $>1000$ \\
\cline { 2 - 7 } & S. & $>1000$ & 1000 & $>1000$ & 1000 & 1000 \\
\hline
\end{tabular}




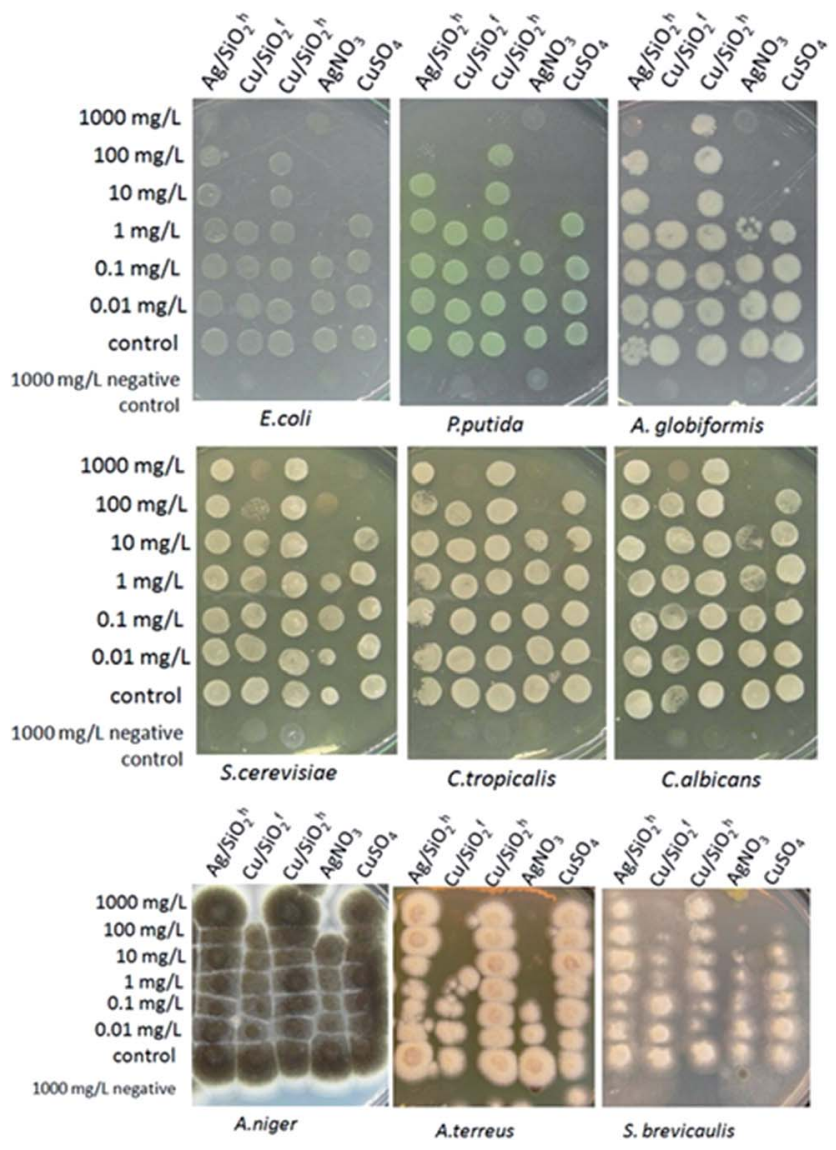

Fig. 8 Colony-forming ability of bacteria, yeast and fungi after $24 \mathrm{~h}$ exposure to $\mathrm{Ag} / \mathrm{SiO}_{2}{ }^{\mathrm{h}}, \mathrm{Cu} / \mathrm{SiO}_{2}{ }^{\mathrm{f}}$ (hydrophilic), $\mathrm{Cu} / \mathrm{SiO}_{2}{ }^{\mathrm{h}}$ (hydrophobic), $\mathrm{Ag}$ - and $\mathrm{Cu}$-ions in deionized water at $24^{\circ} \mathrm{C}$. After exposure, cells (5 $\left.\mu \mathrm{l}\right)$ were transferred onto toxicant-free agarized growth medium.

$380,466, \mathrm{~cm}^{-1}$ assigned to the $\mathrm{Cu}-\mathrm{O}$ vibration ${ }^{73}$ and other ones with lower intensity to the ( $\mathrm{Si}-\mathrm{O})-\mathrm{Cu}$ modes.

Antimicrobial properties of nanocomposites. In order to evaluate the antimicrobial potential of the silver- and coppersilica nanocomposites as well as metal ions used as reference of tested nanomaterials, the 'spot test' experiment have been performed (see Fig. 8 and Table 4). We have simulated a potential exposition as it can be expected in the natural poor nutrient environmental conditions by incubating the analyzed microbial strains in deionized water. ${ }^{37}$ In this test, the toxic effect was not modulated by different growth media, although it allows for the analysis of metallic compounds, which typically showed tendency to form non-bioavailable complexes with ligands in media.

The highest antibacterial effect was observed for hydrophilic $\mathrm{Cu} / \mathrm{SiO}_{2}{ }^{\mathrm{f}}$, for which minimum biocidal concentration (MBC) was determined at the level of $10 \mathrm{mg} \mathrm{L}^{-1}$ after $24 \mathrm{~h}$ (Table 4). The same level of antibacterial properties showed $\mathrm{Cu}$-ions $\left(\mathrm{CuSO}_{4}\right)$, although it should be considered that content of $\mathrm{Cu}$ in synthesized nanocomposites was $2.48 \%$ and $11.77 \%$ for hydrophobic and hydrophilic systems (based on the SEM + EDX analysis), respectively.

Antifungal properties of copper are used especially in agricultural management where copper consists is an active substance of inorganic fungicides. ${ }^{74}$ Moreover, antifungal activity of $\mathrm{Cu}$ NPs may be higher than for commonly used fungicide in bulk. ${ }^{75}$ Hence, to shed more light on the toxic effect of the silica-based nanocomposite, more detailed studies against fungal strains of all systems were carried out. The outcomes showed the $\mathrm{Cu} / \mathrm{SiO}_{2}{ }^{\mathrm{f}}$ composite demonstrated higher toxic effect than $\mathrm{Cu}$-ions. For $\mathrm{A}$. terreus the toxic effect calculated for $\mathrm{Cu} / \mathrm{SiO}_{2}{ }^{\mathrm{f}}$ was more than 100 times higher in comparison with $\mathrm{Cu}$-ions. In contrast, the weakest biocidal effect was observed for $\mathrm{Cu} / \mathrm{SiO}_{2}{ }^{\mathrm{h}}$ nanosystem. This effect might be connected to certain nanoparticles properties such as size or degree of metal agglomeration. ${ }^{76}$ In our study the particle size of hydrophobic $\mathrm{Cu} / \mathrm{SiO}_{2}$ was about 3 times bigger compared to the hydrophilic $\mathrm{Cu} / \mathrm{SiO}_{2}$ nanocomposite. Moreover, $\mathrm{Cu}$ concentration in hydrophobic silica matrix was almost 5 times smaller than hydrophilic one.

Further, the $\mathrm{Ag} / \mathrm{SiO}_{2}$ nanocomposite was determined. However, no toxic effect on the yeast or fungi strains was found. The comparison of $\mathrm{MBC}$ values of the $\mathrm{Ag}$ and $\mathrm{Cu}$ combined with

Table 5 Inhibitory concentration $\left(\mathrm{IC}_{50}\right)$ of nanocomposites and combined with $\mathrm{IC}_{50}$ of $\mathrm{Ag}$ - and $\mathrm{Cu}$-ions for bacterial strain $\left(\mathrm{mg} \mathrm{L}^{-1}\right)^{a}$

\begin{tabular}{|c|c|c|c|c|c|}
\hline Bacterial strain & $\mathrm{Ag} / \mathrm{SiO}_{2}{ }^{\mathrm{h}}$ & $\mathrm{Cu} / \mathrm{SiO}_{2}{ }^{\mathrm{f}}$ & $\mathrm{Cu} / \mathrm{SiO}_{2}{ }^{\mathrm{h}}$ & $\mathrm{AgNO}_{3}$ & $\mathrm{CuSO}_{4}$ \\
\hline E. coli & $96.1 \pm 6.1$ & $81.9 \pm 9.9$ & $78.4 \pm 7.2$ & $8.0 \pm 1.3$ & $555.2 \pm 8.9$ \\
\hline P. putida & $1091.5 \pm 112.9$ & $96.2 \pm 8.8$ & $>1000$ & $5.1 \pm 0.1$ & $512.3 \pm 5.7$ \\
\hline A. globiformis & $>1000$ & $55.0 \pm 3.5$ & $>1000$ & $5.9 \pm 0.2$ & $564.8 \pm 14.1$ \\
\hline
\end{tabular}

\begin{tabular}{|c|c|c|c|c|}
\hline${ }^{a}$ Range of $\mathrm{IC}_{50}$ : & $\begin{array}{c}1-9.9 \mathrm{mg} \\
\mathrm{L}^{-1}\end{array}$ & $\begin{array}{c}10-99 \mathrm{mg} \\
\mathrm{L}^{-1}\end{array}$ & $\begin{array}{c}100-1000 \mathrm{mg} \\
\mathrm{L}^{-1}\end{array}$ & $\begin{array}{c}>1000 \mathrm{mg} \\
\mathrm{L}^{-1}\end{array}$ \\
\hline
\end{tabular}


Table 6 Inhibitory concentration $\left(\mathrm{IC}_{50}\right)$ of nanocomposites and $\mathrm{Ag}$ - and $\mathrm{Cu}$-ions for cell cultures $\left(\mathrm{mg} \mathrm{L}^{-1}\right)$

\begin{tabular}{|c|c|c|c|}
\hline Cell culture & $\mathrm{Ag} / \mathrm{SiO}_{2}{ }^{\mathrm{h}}$ & $\mathrm{Cu} / \mathrm{SiO}_{2}{ }^{\mathrm{f}}$ & $\mathrm{Cu} / \mathrm{SiO}_{2}{ }^{\mathrm{h}}$ \\
\hline NHDF & $>100$ & $>50$ & $>40$ \\
\hline${ }^{a}$ Range of the tested concentrations & $100-25$ & $50-25$ & $40-10$ \\
\hline
\end{tabular}

${ }^{a}$ Solubility depending.

hydrophobic $\mathrm{SiO}_{2}$ showed higher antibacterial effect of nanomaterials contained silver. Similar results have been published by Suppi et al., ${ }^{37}$ where smaller biocidal effect of $\mathrm{Cu}$ NPs in comparison with AgNPs was found.

Inhibitory concentration $\mathrm{IC}_{50}$ test performed on selective bacterial strains revealed lower antibacterial potency compared to the results obtained by 'spot test' (see Table 5). It may indicate that observed toxic effect results not from the disruption of the active growth of bacterial strains, but has general nature. It has been considered, that $\mathrm{Cu}$ - or Ag-based NPs are highly reactive due to their large specific surface area to the bulk one, which may be responsible for inducing generation of the reactive oxygen species. It may affect microorganisms by disruption of cell wall, lipid peroxidation or damage of DNA/RNA. ${ }^{77}$

Similarly, to the results obtained by 'spot test' for all tested nanocomposites, the $\mathrm{CuSiO}_{2}{ }^{\mathrm{f}}$ exerted the highest toxic effect against bacteria and the effect was higher in comparison with $\mathrm{Cu}$-ions. Moreover, all NCs exert toxic effect on gram-negative bacteria E. coli. Toxicity of NPs against bacterial strain was examined also in other studies. ${ }^{78,79}$ It was shown, that silver ions may be released from the surface of $\mathrm{Ag} / \mathrm{SiO}_{2}$ coating films and exerted totally inhibited growth effect on $E$. coli in comparison with $S$. aureus ( $90 \%$ bactericides), due to trapping silver ion by peptidoglycan in the gram-positive cell wall. ${ }^{78}$ This effect is similar to our results, where gram-positive strain of $A$. globiformis showed a lower sensitivity to tested compound compared to E. coli. Additionally, capping of nanoparticles by
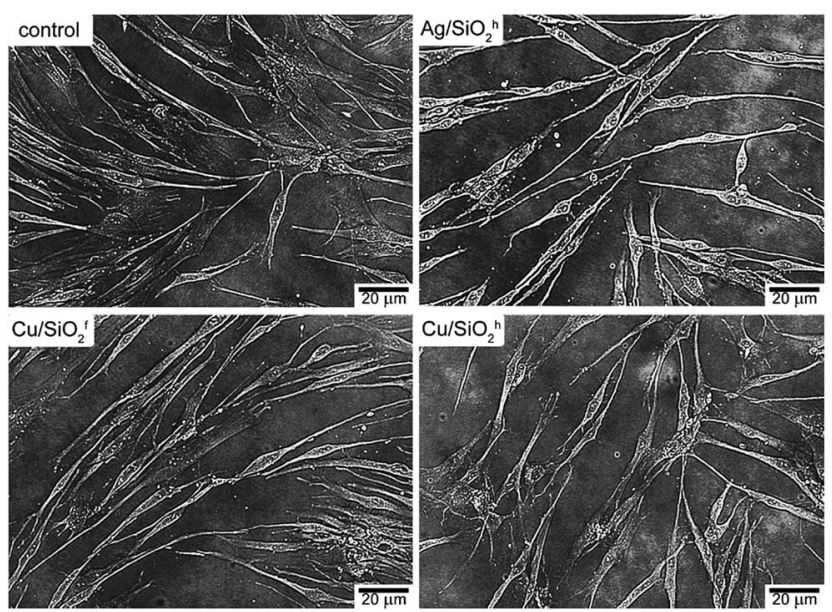

Fig. 9 The cell morphology of NHDF after a $72 \mathrm{~h}$ treatment with control, $\mathrm{Ag} / \mathrm{SiO}_{2}{ }^{\mathrm{h}}, \mathrm{Cu} / \mathrm{SiO}_{2}{ }^{\mathrm{f}}$, and $\mathrm{Cu} / \mathrm{SiO}_{2}{ }^{\mathrm{h}}$. exopolysaccharides produced by bacteria may be responsible for tolerance of bacteria for AgNPs. ${ }^{79}$ This may explain small inhibitory effect of nanomaterials against strain of P. putida G7, which is known as producer of exopolymers. ${ }^{80}$

Cell culture and cytotoxicity assay. Inhibitory concentration test performed relative to the human fibroblast cells was used to assess cell viability and cell proliferation. The outcomes have shown no significant signs of cytotoxicity in case of all tested nanocomposites (Table 6). It may suggest that similar metal concentrations $\left(\mathrm{mg} \mathrm{L}^{-1}\right)$ like applied to the bactericidal tests $\left(\mathrm{IC}_{50} \mathrm{mg} \mathrm{L}^{-1}\right.$ ), does not exclude an active growth of human fibroblast in the solution (Fig. 9). Additionally, no differences in cytotoxicity suggest limitation of negative impact of nano-silver and nano-copper on the human cells.

\section{Conclusions}

This paper has summarized a complete process of production and characterization of metallic (silver, copper) silica-based powder nanocomposites with the use of hydrophilic and hydrophobic silica matrices. Diffraction data revealed presence of amorphous and crystalline silica phases while chemical analysis, heterogeneously distribution of metallic ions and carbon within silica matrix as well as their potential agglomeration in submicron clusters. Microscopy images revealed round-shape morphology of metallic ions as well as evidenced an average size of silver and copper embedded into hydrophobic matrix close to $12 \mathrm{~nm}$, while in case of hydrophilic ones close to $4 \mathrm{~nm}$. Surface sensitive methods indicated the presence of silver and copper oxides, surface adsorbed carbon and stoichiometry and non-stoichiometric silica phases. Infrared and Raman spectroscopy showed presence of major silica-active bands as well as metallic-oxide bonds. Biological test revealed antibacterial and antifungal properties of synthesized nanocomposites, in some cases even better than those reported for silver- or copper-based, commonly used chemical compounds. Significantly, the highest biocidal properties were determined for nanocomposite with smallest particle size and proved the lack of cytotoxic effect of all nanocomposites for the human cells.

\section{Acknowledgements}

A. M. W. is thankful for the financial support from the National Center of Science based on decision 2014/13/D/NZ7/00322. 


\section{References}

1 J. Jiang, S.-H. Kim and L. Piao, Nanoscale, 2015, 7, 8299-8303.

2 G. Ghodake, S.-R. Lim and D. S. Lee, Colloids Surf., B, 2013, 108, 147-151.

3 H. H. Lara, N. V. Ayala-Nuñez, L. Ixtepan-Turrent and

C. Rodriguez-Padilla, J. Nanobiotechnol., 2010, 8, 1.

4 F. Li, C. Lei, Q. Shen, L. Li, M. Wang, M. Guo, Y. Huang, Z. Nie and S. Yao, Nanoscale, 2012, 5, 653-662.

5 W. K. Jung, H. C. Koo, K. W. Kim, S. Shin, S. H. Kim and Y. H. Park, Appl. Environ. Microbiol., 2008, 74, 2171-2178.

6 Nanostructured Materials and Coatings for Biomedical and Sensor Applications, ed. I. V. Uvarova and Y. G. Gogotsi, Springer, Netherlands, 2003, vol. 102.

7 J. R. Morones, J. L. Elechiguerra, A. Camacho, K. Holt, J. B. Kouri, J. T. Ramírez and M. J. Yacaman, Nanotechnology, 2005, 16, 2346.

8 D. Carmona, P. Lalueza, F. Balas, M. Arruebo and J. Santamaría, Microporous Mesoporous Mater., 2012, 161, 84-90.

9 D. M. Eby, H. R. Luckarift and G. R. Johnson, ACS Appl. Mater. Interfaces, 2009, 1, 1553-1560.

10 D. Lee, M. F. Rubner and R. E. Cohen, Chem. Mater., 2005, 17, 1099-1105.

11 Z. Xiu, Q. Zhang, H. L. Puppala, V. L. Colvin and P. J. J. Alvarez, Nano Lett., 2012, 12, 4271-4275.

12 A. Mollahosseini, A. Rahimpour, M. Jahamshahi, M. Peyravi and M. Khavarpour, Desalination, 2012, 306, 41-50.

13 K.-Y. Yoon, J. Hoon Byeon, J.-H. Park and J. Hwang, Sci. Total Environ., 2007, 373, 572-575.

14 S. Suppi, K. Kasemets, A. Ivask, K. Künnis-Beres, M. Sihtmäe, I. Kurvet, V. Aruoja and A. Kahru, J. Hazard. Mater., 2015, 286, 75-84.

15 R. L. Williams, P. J. Doherty, D. G. Vince, G. J. Grashoff and D. F. Williams, Crit. Rev. Biocompat., 1989, 5, 221-243.

16 A. Oloffs, C. Grosse-Siestrup, S. Bisson, M. Rinck, R. Rudolph and U. Gross, Biomaterials, 1994, 15, 753-758.

17 P. van Broekhuizen, F. van Broekhuizen, R. Cornelissen and L. Reijnders, J. Nanopart. Res., 2011, 13, 447-462.

18 J. Lee, S. Mahendra and P. J. J. Alvarez, ACS Nano, 2010, 4, 3580-3590.

19 N. von Goetz, C. Lorenz, L. Windler, B. Nowack, M. Heuberger and K. Hungerbühler, Environ. Sci. Technol., 2013, 47, 9979-9987.

20 S. K. Das, M. M. R. Khan, T. Parandhaman, F. Laffir, A. K. Guha, G. Sekaran and A. B. Mandal, Nanoscale, 2013, 5, 5549-5560.

21 O. V. Abramov, A. Gedanken, Y. Koltypin, N. Perkas, I. Perelshtein, E. Joyce and T. J. Mason, Surf. Coat. Technol., 2009, 204, 718-722.

22 A. Guerrero-Martínez, J. Pérez-Juste and L. M. Liz-Marzán, Adv. Mater., 2010, 22, 1182-1195.

23 J.-P. Kaiser, S. Zuin and P. Wick, Sci. Total Environ., 2013, 442, 282-289.

24 A. Mandal, S. Sekar, K. M. S. Meera, A. Mukherjee, T. P. Sastry and A. B. Mandal, Phys. Chem. Chem. Phys., 2014, 16, 20175-20183.
25 A. Mandal, S. Sekar, N. Chandrasekaran, A. Mukherjee and T. P. Sastry, J. Mater. Chem. B, 2015, 3, 3032-3043.

26 A. Mandal, S. Sekar, N. Chandrasekaran, A. Mukherjee and T. P. Sastry, RSC Adv., 2015, 5, 15763-15771.

27 A. Mandal, V. Meda, W. J. Zhang, K. M. Farhan and A. Gnanamani, Colloids Surf., B, 2012, 90, 191-196.

28 A. Mandal, S. Sekar, N. Chandrasekaran, A. Mukherjee and T. Sastry, Proc. Inst. Mech. Eng., Part H, 2013, 227, 1224-1236.

29 Y. Dong, T. Liu, S. Sun, X. Chang and N. Guo, Ceram. Int., 2014, 40, 5605-5609.

30 G. R. Raghav, A. N. Balaji, K. Murugan and B. HarishKumar, International Research Journal of Engineering Science, Technology and Innovation, 2014, 3, 1368-1373.

31 M. K. Gangishetty, R. W. J. Scott and T. L. Kelly, Dalton Trans., 2016, 45, 9827-9834.

32 A. Nowak, J. Szade, E. Talik, A. Ratuszna, M. Ostafin and J. Peszke, Mater. Chem. Phys., 2014, 145, 465-470.

33 A. Nowak, J. Szade, E. Talik, M. Zubko, D. Wasilkowski, M. Dulski, K. Balin, A. Mrozik and J. Peszke, Mater. Charact., 2016, 117, 9-16.

34 J. Peszke, A. Nowak, J. Szade, A. Szurko, D. Zygadło, M. Michałowska, P. Krzyściak, P. Zygoń, A. Ratuszna and M. M. Ostafin, J. Nanopart. Res., 2016, 18, 355.

35 K. Dudek, J. Podwórny, M. Dulski, A. Nowak and J. Peszke, Powder Diffr., 2017, 1-5.

36 Z. Li, L. Jia, Y. Li, T. He and X.-M. Li, Appl. Surf. Sci., 2015, 345, 122-126.

37 S. Suppi, K. Kasemets, A. Ivask, K. Künnis-Beres, M. Sihtmäe, I. Kurvet, V. Aruoja and A. Kahru, J. Hazard. Mater., 2014, 286C, 75-84.

38 S. Suppi, K. Kasemets, A. Ivask, K. Künnis, I. Kurvet, V. Aruoja and A. Kahru, J. Hazard. Mater., 2014, 1-9.

39 E. M. Flanigen, J. M. Bennett, R. W. Grose, J. P. Cohen, R. L. Patton, R. M. Kirchner and J. V. Smith, Nature, 1978, 271, 512-516.

40 2012, NIST X-ray Photoelectron Spectroscopy Database, Version 4.1 (National Institute of Standards and Technology, Gaithersburg, 2012); http://srdata.nist.gov/xps/.

41 L. Armelao, D. Barreca, G. Bottaro, A. Gasparotto, C. Maragno and E. Tondello, Surf. Sci. Spectra, 2003, 10, 170-181.

42 J.-Y. Park, K.-A. Lim, R. D. Ramsier and Y.-C. Kang, Bull. Korean Chem. Soc., 2011, 32, 3395-3399.

43 J. F. Moulder, W. F. Stickle, P. E. Sobol and K. D. Bomben, Handbook of X Ray Photoelectron Spectroscopy: A Reference Book of Standard Spectra for Identification and Interpretation of Xps Data, Physical Electronics, Eden Prairie, Minn, 1995.

44 F. J. Himpsel, F. R. McFeely, A. Taleb-Ibrahimi, J. A. Yarmoff and G. Hollinger, Phys. Rev. B: Condens. Matter Mater. Phys., 1988, 38, 6084-6096.

45 E. Cano, C. L. Torres and J. M. Bastidas, Mater. Corros., 2001, 52, 667-676.

46 O. Akhavan, M. Abdolahad, A. Esfandiar and M. Mohatashamifar, J. Phys. Chem. C, 2010, 114, 12955-12959. 47 M. S. A. S. Shah, K. Zhang, A. R. Park, K. S. Kim, N.-G. Park, J. H. Park and P. J. Yoo, Nanoscale, 2013, 5, 5093-5101. 
48 S. Ramalingam, L. B. Devi, J. R. Rao and B. U. Nair, RSC Adv., 2014, 4, 56041-56051.

49 H. Naeimi and V. Nejadshafiee, New J. Chem., 2014, 38, 54295435.

50 F. Zhao, X. Wang, B. Ding, J. Lin, J. Hu, Y. Si, J. Yu and G. Sun, RSC Adv., 2011, 1, 1482-1488.

51 D. Das, P. Choudhury, L. Bortahkur, B. Gogoi, A. K. Buragohain and S. K. Dolui, RSC Adv., 2014, 5, 23602367.

52 O. Shameema, C. N. Ramachandran and N. Sathyamurthy, J. Phys. Chem. A, 2006, 110, 2-4.

53 H. Moghanian, A. Mobinikhaledi, A. G. Blackman and E. Sarough-Farahani, RSC Adv., 2014, 4, 28176.

54 A. Alessi, S. Agnello, G. Buscarino and F. M. Gelardi, J. Raman Spectrosc., 2013, 44, 810-816.

55 T. Deschamps, H. Vezin, C. Gonnet and N. Ollier, Opt. Express, 2013, 21, 8382.

56 T. Sato, N. Funamori and T. Yagi, Nat. Commun., 2011, 2, 345.

57 L. Robinet, C. Coupry, K. Eremin and C. Hall, J. Raman Spectrosc., 2006, 37, 789-797.

58 D. W. Matson, S. K. Sharma and J. A. Philpotts, J. Non-Cryst. Solids, 1983, 58, 323-352.

59 V. K. Sharma, R. A. Yngard and Y. Lin, Adv. Colloid Interface Sci., 2009, 145, 83-96.

60 P. McMillan, Am. Mineral., 1984, 69, 645-659.

61 N. Kitamura, K. Fukumi, H. Mizoguchi, M. Makihara, A. Higuchi, N. Ohno and T. Fukunaga, J. Non-Cryst. Solids, 2000, 274, 244-248.

62 G. S. Henderson, G. M. Bancroft and M. E. Fleet, Am. Mineral., 1985, 70(9), 946-960.

63 G. Vaccaro, S. Agnello, G. Buscarino and F. M. Gelardi, J. Phys. Chem. C, 2010, 114, 13991-13997.

64 F. L. Galeener and A. E. Geissberger, Phys. Rev. B: Condens. Matter Mater. Phys., 1983, 27, 6199-6204.
65 I. Martina, R. Wiesinge, D. Jembrih-Simbürger and M. Schreiner, e-Preserv. Sci., 2012, 9, 1-8.

66 Infrared and Raman Characteristic Group Frequencies: Tables and Charts, ed. G. Socrates, Wiley-VCH Verlag $\mathrm{GmbH} \& \mathrm{Co}$. KGaA, 3rd edn, 2004.

67 A. E. Geissberger and F. L. Galeener, Phys. Rev. B: Condens. Matter Mater. Phys., 1983, 28, 3266-3271.

68 T. Seuthe, M. Grehn, A. Mermillod-Blondin, H. J. Eichler, J. Bonse and M. Eberstein, Opt. Mater. Express, 2013, 3, 755.

69 J. F. Xu, W. Ji, Z. X. Shen, W. S. Li, S. H. Tang, X. R. Ye, D. Z. Jia and X. Q. Xin, J. Raman Spectrosc., 1999, 30, 413-415.

70 H. F. Goldstein, D. Kim, P. Y. Yu, L. C. Bourne, J.-P. Chaminade and L. Nganga, Phys. Rev. B: Condens. Matter Mater. Phys., 1990, 41, 7192-7194.

71 H. Y. H. Chan, C. G. Takoudis and M. J. Weaver, J. Phys. Chem. B, 1998, 103, 357-365.

72 T. Yu, X. Zhao, Z. X. Shen, Y. H. Wu and W. H. Su, J. Cryst. Growth, 2004, 268, 590-595.

73 A. Bhaumik, A. M. Shearin, R. Patel and K. Ghosh, Phys. Chem. Chem. Phys., 2014, 16, 11054-11066.

74 A. M. Wightwick, S. a. Salzman, S. M. Reichman, G. Allinson and N. W. Menzies, Environ. Sci. Pollut. Res., 2013, 20, 15741585.

75 P. Kanhed, S. Birla, S. Gaikwad, A. Gade, A. B. Seabra, O. Rubilar, N. Duran and M. Rai, Mater. Lett., 2014, 115, 13-17.

76 T. Silva, L. R. Pokhrel, B. Dubey, T. M. Tolaymat, K. J. Maier and X. Liu, Sci. Total Environ., 2014, 468-469, 968-976.

77 C. Civardi, M. Schubert, A. Fey, P. Wick and F. W. M. R. Schwarze, PLoS One, 2015, 10, e0142578.

78 N. Baheiraei, F. Moztarzadeh and M. Hedayati, Ceram. Int., 2012, 38, 2921-2925.

79 S. Khan, A. Mukherjee and N. Chandrasekaran, J. Environ. Sci., 2011, 23, 346-352.

80 S. C. Kachlany, S. B. Levery, J. S. Kim, B. L. Reuhs, L. W. Lion and W. C. Ghiorse, Environ. Microbiol., 2001, 3, 774-784. 